University of Louisville

ThinkIR: The University of Louisville's Institutional Repository

Electronic Theses and Dissertations

8-2009

\title{
Would you like to talk? : the impact of media and interpersonal communication on knowledge about candidates and likelihood of voting.
}

Donna M. Elkins 1968-

University of Louisville

Follow this and additional works at: https://ir.library.louisville.edu/etd

\section{Recommended Citation}

Elkins, Donna M. 1968-, "Would you like to talk? : the impact of media and interpersonal communication on knowledge about candidates and likelihood of voting." (2009). Electronic Theses and Dissertations. Paper 397.

https://doi.org/10.18297/etd/397

This Master's Thesis is brought to you for free and open access by ThinkIR: The University of Louisville's Institutional Repository. It has been accepted for inclusion in Electronic Theses and Dissertations by an authorized administrator of ThinkIR: The University of Louisville's Institutional Repository. This title appears here courtesy of the author, who has retained all other copyrights. For more information, please contact thinkir@louisville.edu. 


\title{
WOULD YOU LIKE TO TALK?: \\ THE IMPACT OF MEDIA AND INTERPERSONAL COMMUNICATION ON KNOWLEDGE ABOUT CANDIDATES AND LIKELIHOOD OF VOTING
}

By

Donna M. Elkins

$\mathrm{PhD}$, University of Kentucky, 2005

\author{
A Thesis \\ Submitted to the Faculty of the \\ Graduate School of the University of Louisville \\ in Partial Fulfillment of the Requirements \\ for the Degree of
}

Master of Arts

\author{
Department of Political Science \\ University of Louisville \\ Louisville, Kentucky
}

August 2009 
WOULD YOU LIKE TO TALK?:

THE IMPACT OF MEDIA AND INTERPERSONAL COMMUNICATION ON KNOWLEDGE ABOUT CANDIDATES AND LIKELIHOOD OF VOTING

By

Donna M. Elkins

$\mathrm{PhD}$, University of Kentucky, 2005

A Thesis Approved on

July 22,2009

by the following Thesis Committee:

Thesis Director 


\section{DEDICATION}

This thesis is dedicated to my husband

Douglas J. Elkins

who has always supported me and given invaluable advice,

feedback, and encouragement along the way. 


\section{ACKNOWLEDGMENTS}

I would like to thank my major professor, Dr. Laurie Rhodebeck, for her willingness to work with me, her patience in explaining a new area of research to me, her always supportive attitude and her input that added substantially to the content and quality of this work. I would also like to thank the other committee members, Dr. Jason Gainous, for his support and input, and Dr. Margaret D'Silva, for comments and assistance. I also thank the faculty in the Department of Political Science at the University of Louisville. They provided me all necessary instruction and willingly helped me understand the intricacies of a new discipline. I would also like to express my thanks to my husband, Doug, who never complained about the many weekends I spent working. Also, I want to thank my fellow faculty and staff at Jefferson Community and Technical College, who are the best colleagues one could wish for when engaging in academic pursuits. 


\begin{abstract}
WOULD YOU LIKE TO TALK?:

THE IMPACT OF MEDIA AND INTERPERSONAL COMMUNICATION ON KNOWLEDGE ABOUT CANDIDATES AND LIKELIHOOD OF VOTING
\end{abstract}

Donna M. Elkins

July 22,2009

Scholars have long considered the role media play in shaping levels of political knowledge and voting behavior. The specific context of this study is the 2000 and 2004 presidential elections. It examines the influence of newspaper reading, television viewing, Internet use and interpersonal communication on levels of candidate issue and background knowledge and likelihood to vote.

The results testify to the influence of media in citizens' level of knowledge about presidential candidates. The results also provide a confirmation of the limited impact of Internet campaigning in the 2000 presidential election (Weaver \& Drew, 2001) and show increased impact in the 2004 election. In addition, the results confirm the significance of interpersonal discussion to heightening levels of political knowledge (Feldman \& Price, 2008; Huckfeldt \& Sprague, 1995). Interpersonal communication about the campaign was also a significant factor predicting whether a citizen would vote in both of these presidential election years. 


\section{TABLE OF CONTENTS}

PAGE

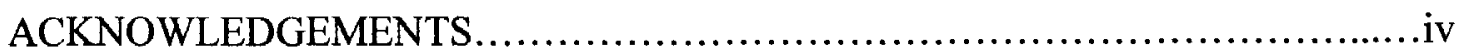

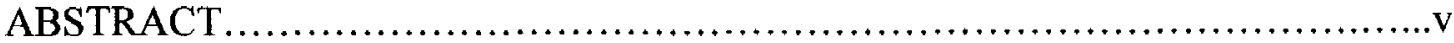

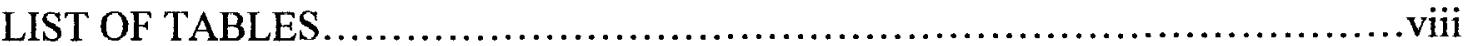

\section{CHAPTER}

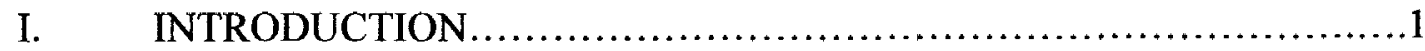

Contributions of this Study .........................................

The 2000 and 2004 Presidential Elections...........................4

II. LITERATURE REVIEW ...........................................6

Theories of Media Influence........................................

The Role of Interpersonal Communication............................12

The Role of the Internet........................................... 16

Previous Studies....................................................17

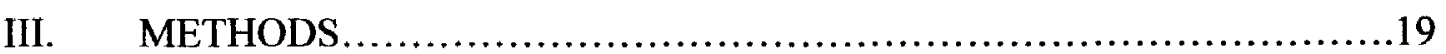

Hypotheses and Research Questions.............................19

Samples and Source of Data.........................................20

Media Use......................................................22

Interpersonal Discussion...........................................23

Candidate Issue Knowledge......................................23

Candidate Background Knowledge.................................24

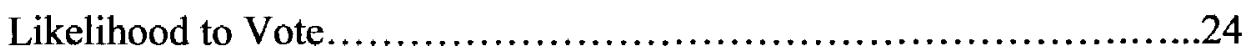




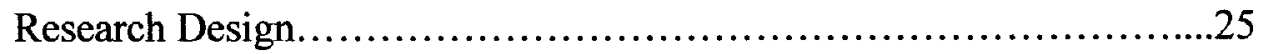

IV. RESULTS - RELATIONSHIPS AMONG VARIABLES.................27

Descriptive Statistics............................................27

Hypothesis One: Candidate Issue Knowledge..........................30

Hypothesis Two: Candidate Background Knowledge....................31

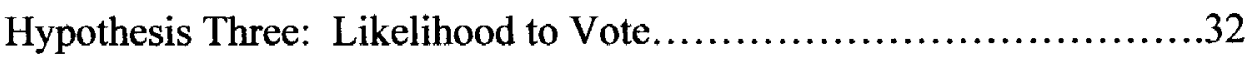

Research Question One: Media Use and Interpersonal Discussion.......33

Comparisons in 2000 and 2004 Correlations..........................34

V. RESULTS - ROLE OF INTERPERSONAL COMMUNICATION...........36

Research Question Two: Influence of Interpersonal Discussion...........36

Interpersonal Communication and Candidate Issue Knowledge............36

Interpersonal Communication and Candidate Background Knowledge...38

Interpersonal Communication and Likelihood to Vote....................39

Overall Model Fit...................................................... 41

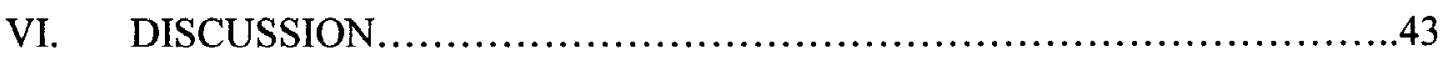

Overall Findings..................................................... 43

Importance of This Research.......................................45

Weaknesses of This Study .........................................46

Questions for Future Research...................................48

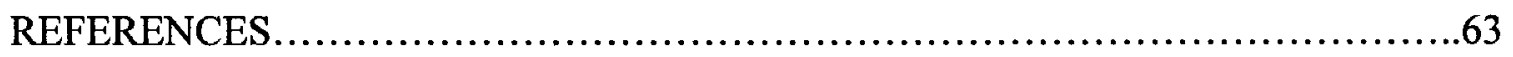

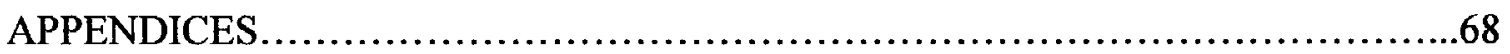

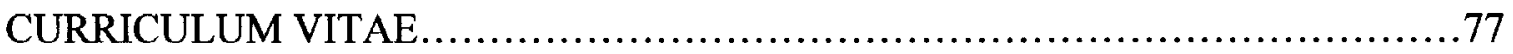




\section{LIST OF TABLES}

TABLE

PAGE

1. Descriptive Statistics for Variables in 2000 Presidential Election.........51

2. Descriptive Statistics for Variables in 2004 Presidential Election.........52

3. Correlation Matrix for Variables in 2000 Presidential Election...........53

4. Correlation Matrix for Variables in 2004 Presidential Election...........54

5. Linear Regression on Candidate Issue Knowledge in 2000 Presidential Election. .55

6. Linear Regression on Candidate Issue Knowledge in 2004 Presidential

Election.

7. Linear Regression on Candidate Background Knowledge in 2000

Presidential Election.

8. Linear Regression on Candidate Background Knowledge in 2004

Presidential Election. .58

9. Binary Logistic Regression on Likelihood to Vote in 2000 Presidential Election

10. Binary Logistic Regression on Likelihood to Vote in 2004 Presidential Election.

11. Crosstabs of Likelihood to Vote and Interpersonal Discussion in 2000

Presidential Election. 
12. Crosstabs of Likelihood to Vote and Interpersonal Discussion in 2004

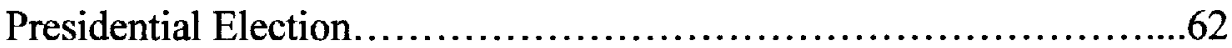

13. Frequencies for Variables in 2000 Presidential Election................75

14. Frequencies for Variables in 2004 Presidential Election..................76 


\section{CHAPTER ONE}

\section{INTRODUCTION}

Since the early days of televised media, communication and political science scholars have questioned the impact of media on citizens' political knowledge and thereby, their political choices. Early theories proposed a strong 'magic bullet' role for the media that quickly became the idea of a softer "two-step flow" whereby media and interpersonal interactions combined to have impact (Lowery \& DeFleur, 1995; Weaver \& Drew, 2001; Weimann, 1982; Wyatt, Katz \& Kim, 2000). But questions remain about how strong the impact of media truly is when it comes to political knowledge and voter choices, and how influential talking with others is in the process.

Researchers have attempted to answer the questions about the effect of media and interpersonal communication on political knowledge through a myriad of studies. Depending on the type of election and the media sources chosen for examination political ads, television news, political debates and/or newspaper articles - different types of media have been found to weigh most heavily in voters' knowledge about candidates' issue positions (Abrajano \& Singh, 2009; Brians \& Wattenburg, 1996; Craig, Kane \& Gainous, 2005; Eveland, Hays, Shah \& Kwak, 2005; Feldman \& Price, 2008; Kwak, Williams, Wang \& Lee, 2005; Weaver \& Drew, 2001). Holbert (2005) has argued that these contradictory findings are indicative of the failure to consider the intermediation 
relationship of different forms of media, especially over the course of a campaign. Media use and interpersonal discussion have usually been treated in these studies as two independent variables in the prediction of political learning, although recently researchers have turned to look at the two as having a more complete interactive effect (deBoer \& Velthuijsen, 2001; Feldman \& Price, 2008). Findings have also suggested that the nature of the interactive effect may be dependent on the form of mass media involved (Eveland, Hays, Shah \& Kwak, 2005; Feldman \& Price, 2008).

Mixed results from previous studies attempting to examine the interactive role of media and interpersonal discussion have left it unclear as to whether interpersonal discussion has an additive effect when it comes to political knowledge or merely acts as a distraction to create more ambivalence in potential voters (deBoer \& Velthuijsen, 2001; Feldman \& Price, 2008; Lenart, 1994; Scheufele, 2002). Speculation that interpersonal discussion with dissimilar others might actually produce confusion has led some researchers to look at the nature of interpersonal disagreement over political issues (Feldman \& Price, 2008; Mutz \& Martin, 2001). Likewise political discussion in heterogeneous neighborhoods (Huckfeldt \& Sprague, 1995; Kwak, Williams, Wang \& Lee, 2005) has been studied. Feldman and Price (2008) built on previous research by choosing three different media outlets - newspapers, television news and candidate debates - and looking at the interactive effects of not only interpersonal discussion with like-minded individuals, but with interpersonal discussion between individuals who disagreed, theorizing that political disagreement should enhance political issue learning.

One form of media not included in most of these previous studies is the Internet. Early research into the role of the Internet in campaigning has found less impact on 
voters' knowledge about candidates than might be expected (Weaver \& Drew, 2001). But since the publication of Weaver and Drew's findings, the use of the Internet for campaigning in presidential elections has expanded substantially.

Studies examining media and discussion variables have found varying results due in part to the type of election considered. Some studies have looked at primaries (Feldman \& Price, 2008), some have studied senatorial or gubernatorial elections (Brians

\& Wattenberg, 1996; Craig, Kane \& Gainous, 2005) and most have used varying national election survey results over a wide span of years. These varying research findings about the role of media in the form of newspapers, television news, and Internet use have not definitively answered the questions about the effects of the media, coupled with interpersonal discussion, on individuals' level of knowledge about candidates. There is still need to research the influence of media and interpersonal discussion on political knowledge and behavior.

Contributions of this Study

With previous research findings in mind, this study examines citizens' knowledge about candidates' issue positions and background and citizens' likelihood to vote in light of personal media access and reported levels of political discussion with family members, friends and co-workers. Thus, this study provides one more context to add to the understanding of the political impact various forms of media and interpersonal discussion have on political learning and, more importantly, adds to the knowledge base of the newly evolving use of the Internet in political campaigning. The specific context focuses on the presidential elections of 2000 and 2004 . 
The 2000 and 2004 Presidential Elections

The 2000 presidential election pitted Republican candidate George W. Bush (with vice-presidential candidate Dick Cheney) against Democratic candidate Al Gore (with vice-presidential candidate Joe Lieberman). The election is probably best remembered for its incredible closeness and the long process for deciding who won based upon the voter recount in the state of Florida. The outcome was finally decided by the U.S. Supreme Court, after much discussion of "hanging chads" and other ballot irregularities on voter punch-out cards.

Media coverage in the election tended to focus on campaign tactics, fund raising and candidate strategies instead of issues. The Project for Excellence in Journalism at Columbia University concluded that 80 percent of the news coverage focused on the campaign instead of issues and a study conducted by the Norman Lear Center at the USC Annenberg School for Communication found that 77 percent of the stories focused on campaign strategy (Weaver \& Drew, 2001). But even more relevant to this study is that the 2000 presidential election was the first to make "extensive use of the Internet and web sites as channels of communication between candidates and voters" (Weaver \& Drew, 2001, p. 787).

The 2004 election once again featured now incumbent Republican President George W. Bush (with Vice-President Dick Cheney) against Democratic candidate John Kerry (with vice-presidential candidate John Edwards). Because Bush was an incumbent, voters had a stronger sense of his personality and policy issues. The aftermath of September 11,2001, and the war in Iraq were two of the issues on the minds of voters early in the election, with the economy and jobs rising to the top of voters' lists 
as the campaign progressed (West, 2008). Throughout the election, the Bush campaign maintained the focus heavily on foreign affairs (West, 2008). The 2004 election was close, hinging on the final vote count in Ohio. Kerry did not protest the results when Bush was announced the winner on the day following the election.

Negative campaign ads were one of the 'big stories' of the 2004 election. Many of these ads focused on Kerry's supposed weakness in the domains of military funding and terrorism. One of the Bush campaign's most memorable ads featured a wolf running through the forest while a background voice described Kerry's voting to cut military spending after the September 11 attack (West, 2008). In general, Kerry's ads were more positive than Bush's spots. A Washington Post study (Kurtz, 2004) pointed out that 52 percent of Bush's ads were attack-oriented, compared to 19 percent of Kerry's.

Another media phenomenon of the 2004 presidential election was the introduction of candidate blogs, a new way of using the Internet in the campaigns.' Both Bush and Kerry maintained a blog as a part of their Internet campaign strategy. These two very different campaigns provide the backdrop for this study of the media's role and the impact of interpersonal communication on citizens' political knowledge and likelihood to vote.

\footnotetext{
${ }^{1}$ Democratic candidate Howard Dean, running in the presidential primary, was the first to create a blog as a part of his Internet campaign strategy. Dean's blog began in March of 2003 and targeted younger voters specifically. The readership of Dean's blog rose to 30,000 visitors per day by September of 2003 (Rice, 2003).
} 


\section{CHAPTER TWO}

\section{LITERATURE REVIEW}

In the early days of televised media, communication scholars theorized a 'magic bullet' effect of the media on political opinions. However, right away those conducting research into media effects on the public began to discover that the effect was not as powerful as first expected. In the 1950s Carl Hovland and Paul Lazarsfeld conducted experiments in Erie County that pointed to the significance of social ties between members of the media's audience; these ties acted as an intermediary for the effect of the media. Their findings led other researchers to surmise and seek to prove a 'two-step flow' in media effects (Lowery \& DeFleur, 1995; Weaver \& Drew, 2001; Wyatt, Katz \& Kim, 2000).

Some scholars turned from treating media as a powerful influence to discussing minimal effects of the media, which led some to declare media studies as no longer worthwhile (Lowery \& DeFleur, 1995). However, Elihu Katz and Paul Lazersfeld were engaged in a large-scale study to examine the indirect effects of the mass media during a presidential campaign (1955). This research probed the role of opinion leaders and the influence that they carry in concert with the media in the two-step flow of communication. The concept of a two-step flow from a political opinion leader downward was soon expanded to multistep flow, horizontal flow and upward flow 
concepts that took into account the role of opinion leaders, but also other directions of information flow from one group to another, between family members and friends and among members of groups (Huckfeldt \& Sprague, 1995; Weimann, 1982). In sum, "the two-step flow concept presumed a movement of information through interpersonal networks, from the media to people and from there to other people, rather than directly from media to mass" (Lowery \& DeFleur, 1995, p. 192). A study conducted by Druckman and Parkin in 2005 demonstrates the mediated impact of newspaper reading on vote choice, for instance. The results of this study found that vote choice is determined more directly by party identification and feelings about the candidates than by the editorial slant of the newspapers read (Druckman \& Parkin, 2005).

These findings do not negate the role of media in politics. The role of media in communicating political knowledge has been demonstrated across a variety of election contexts (Brians \& Wattenburg, 1996; Craig, Kane \& Gainous, 2005; Eveland, Hays, Shah \& Kwak, 2005; Feldman \& Price, 2008; Weaver \& Drew, 2001). Research findings have indicated that various forms of media use are significantly correlated to levels of political knowledge and participation, depending on the election (Weaver \& Drew, 2001). In an early study of the effect of media on political attitudes and beliefs of black voters, Mathews and Prothro (cited in Falk, 2008, p. 22) found that more media exposure increased the likelihood of participation and interest in politics, regardless of education level. In their study, newspaper reading had more of an effect than watching television. Brians and Wattenburg (1996) found that political ads, rather than television news or newspaper articles are more important to respondents' knowledge about candidates' issue 
positions, especially in later stages of the campaign, ${ }^{2}$ but later studies found television news most important (Feldman \& Price, 2008). Television news, more than radio, newspapers or magazines, has shown an ability to "prime" audiences into thinking about certain issues or events (Abrajano \& Singh, 2009). Yet others found newspaper coverage having paramount influence on political knowledge (Kwak, Williams, Wang \& Lee, 2005).

Holbert (2005) has argued that these contradictory findings are indicative of the failure to consider the intermediation relationship of different forms of media, especially over the course of a campaign. Mass communication scholars know that one type of media can influence another, forming a complementary relationship, and so it is reasonable to think this is true in political communication processes as well (Holbert, 2005). Looking at the interaction between newspaper reading and television news viewing content over time, the intermediation effect of these two forms of media was seen to significantly affect voter issue knowledge about various groups' presidential campaign endorsements. Based on these findings, Holbert (2005) argued for researching the interactive effects of media as complementary rather than viewing one form of media use as being in competition with some other media form.

So how do the media affect public opinion and knowledge? Paul Lazarsfeld and Robert Merton (1948) argued that mass media confer status on issues, people, organizations and social movements simply by covering them, calling the phenomenon "status conferral." "The mass media bestow prestige and enhance the authority of

\footnotetext{
${ }^{2}$ Craig, Kane \& Gainous (2005) found that issue learning did increase over the course of the gubernatorial race in the state of Florida, but questioned whether it was due to any form of mass media. Their findings indicated that "what mattered most was general political knowledge and prior awareness of candidate issue stands and sources of group support, with the informationally rich becoming richer as the flow of information increased over time" (p. 495).
} 
individuals and groups by legitimizing their status. Recognition by the press or radio or magazines or newsreels testifies that one has arrived, that one is important enough to have been singled out from the large anonymous masses, and that one's behavior and opinions are significant enough to require public notice (Lazarsfeld \& Merton, 1948, p. 101). If candidates are overlooked by the national media, for whatever reason, they do not exist as a "national common conception" (Falk, 2008). Increased media exposure has for many years been linked to increased levels of candidate recognition (Goldenberg \& Traugott, 1987). Depending on the media, thousands or millions of people may be exposed to the same message about a candidate.

\section{Theories of Media Influence}

Various theories have been formed that focus on the media's ability to influence people's actions and beliefs. Agenda setting has become a well-accepted account of media effects. Bernard Cohen first theorized, "If we do not see a story in the newspaper...it effectively has not happened as far as we are concerned...[T]he press...may not be successful much of the time in telling people what to think, but it is stunningly successful in telling its readers what to think about' (Cohen, 1963, p. 13). Agenda setting is generally accepted as the process by which news outlets focus on certain issues more than others and, thereby, affect the issues that individuals think about and the perspective they have on the issue (Abrajano \& Singh, 2009). A 1972 study of agenda setting is more widely cited to document the role of media in determining what is seen as most important (McCombs \& Shaw, 1972). McCombs and Shaw concluded that the media "exerted a considerable impact on voters' judgments of what they considered the major issues of the campaign" (p. 180). lyengar and Kinder (1987) manipulated the 
media exposure subjects saw and found that people's identification of the country's most important problem varied, depending on the media to which they had been exposed. Likewise, Abrajano and Singh (2009) found that the Latinos' political thought was influenced by the media outlets they used. In that case, Latinos who used Spanish news sources were more aware of immigration initiatives and held more favorable views of illegal immigrants than did Latinos who relied primarily on English news sources (Abrajano \& Singh, 2009).

A second theory focuses on how the media frames or portrays issues. Erving Goffman identified the importance of how an issue is 'framed'. Frames "allow people to locate, perceive, and label" events; in other words, frames provide a way for people to think about life (Goffman in Marks, et al., 2002). Framing commonly involves general coverage of a topic in the media, including how much coverage the topic is given, where it is placed in the media, the definitions and terms used to discuss the issue and the evaluation the issue is given. Framing suggests that news texts are "a system of organized signifying elements that both indicate the advocacy of certain ideas and provide devices to encourage certain kinds of audience processing of texts" (Pan \& Kosicki, 1993, p. 55-56). Robert Entman (1993) defined framing as selecting "some aspects of a perceived reality and mak[ing] them more salient in communicating text, in such a way as to promote a particular problem definition, causal interpretation, more evaluation, and/or treatment recommendation" (p. 52). Two studies that support this definition found that manipulating the order of words in a story, even if the basic story was the same, could influence people's understanding of the topic. Kahneman and Tversky (1984) had people read about a disease outbreak and framed the consequences 
in terms of either how many people would survive the disease or how many would die. Even though the same number of people would survive in either scenario, people preferred the stories that emphasized how many would live. Iyengar (1991) found that when a story focused on a specific unwed mother, the readers were more likely to blame the problem of poverty on the poor themselves. Conversely, when the story focused only on statistics and not on individual stories, people were more likely to blame systemic factors. Message frames have thus been shown to influence such diverse opinions as causal attributions about social problems and levels of political cynicism (Lee, McLeod \& Shah, 2008).

A third theory is cultivation theory, based on the power of television to convey a collective reality. George Gerbner and Larry Gross (1976) first posited cultivation theory as a means of creating a common understanding of social reality. Cultivation theory argues that television creates a basic view of society more so than influencing certain beliefs. Researchers have found that frequent television viewers, for instance, see the world as more violent and have a distorted view of how many people work in various professions (Falk, 2008). The power of the media is this creation of a uniform message for such a large audience in a way that personal experiences and interpersonal communication with others cannot (Falk, 2008).

A fourth theory, one of uses-and-gratification, is that people use mass media as a way of meeting their own needs and choose news content based on their own motives. For instance, if one wants an in-depth description of an event, a newspaper or Internet account would be more likely to meet their needs than a short television news piece. Huckfeldt and Sprague (1995) in Citizens, Politics, and Social Communication found 
that the likelihood of discussing politics with others is also influenced by individual, social and political motives. So, environmental factors create varied information and communication contexts that influence individuals' motivation, and, therefore, shape their communication behavior (Cho, 2008, p. 425).

\section{The Role of Interpersonal Discussion}

These theories and research findings point to the importance, not only of media sources, but also of interpersonal communication in determining political views, thoughts and motivations. In addition to the mass media, interpersonal discussion has been found to be important in learning about political and campaign issues (deBoer \& Velthuijsen, 2001; Cho, 2008; Eveland, Hays, Shah \& Kwak, 2005; Feldman \& Price, 2008; Huckfeldt \& Sprague, 1995; McLeod, Scheufele, \& Moy, 1999; Scheufele, 2000). Citizens' everyday communication practices may revise the view of elite-driven politics, suggesting that citizens are not simply a passive public influenced by media messages, but instead active political actors in the political campaign communication process (Cho, 2008).

For the most part studies of media use and interpersonal discussion have treated these two variables as independent in the prediction of political learning, although recently researchers have turned to look at the two as having a more complete interactive effect (deBoer \& Velthuijsen, 2001; Feldman \& Price, 2008). In order to determine the personal relevance of information obtained through the mass media, people may validate new information through conversation (deBoer \& Velthuijsen, 2001). Findings have also suggested that the nature of the interactive effect may be dependent on the form of mass media involved. For instance, additive effects of interpersonal discussion have been seen 
when coupled with newspaper and Internet use, but interactive effects have been negative when interpersonal discussion is coupled with television media (Eveland, Hays, Shah \& Kwak, 2005; Feldman \& Price, 2008). Cho (2008) found that people who were contacted by political parties or organizations during campaigns were more likely to engage in other communication activities, such as national television news use, newspaper reading and Internet use of campaign information, and interpersonal political discussion. These results suggest that interpersonal campaign channels play a significant role in encouraging individual political communication.

Lenart (1994) found when looking at these interactions that interpersonal discussion actually diminished the positive candidate knowledge effects of viewing a debate and other forms of news exposure. Later research created a model of 'differential gains' from mass media, which indicated that the frequency of interpersonal talking about politics enriched levels of current events knowledge when coupled with newspaper use by compensating for information missing in the media coverage (Scheufele, 2002). ${ }^{3}$ The more a person is exposed to media coverage of a political issue, the more likely he or she will engage in conversations about that topic (deBoer \& Velthuijsen, 2001). These results have left it unclear as to whether interpersonal discussion has an additive effect when it comes to political knowledge or merely acts as a distraction to create more ambivalence in potential voters. To confuse the issue further, a large study that included 17 separate tests of interactions between newspaper and television coverage and interpersonal discussion, presented by Eveland and Scheufele and recorded in Feldman and Price's article (2008), found conflicting results. Eveland and Scheufele termed their

\footnotetext{
${ }^{3}$ Katz \& Lazersfeld (1955) theorized that conversations with others provide an additional opportunity for exposure to content beyond the exposure to the news media and thus lead to increased political learning.
} 
findings the "communication confusion" model because only six of the 17 tests showed significant results and of those, five concurred with Lenart's (1994) findings that discussion detracted from the positive candidate knowledge gathered from the media (Feldman \& Price, 2008, p. 62). ${ }^{4}$

Interpersonal discussion in and of itself is often measured simply by how often or how many people the respondent reports talking to about political candidates and issues. This leaves much nuance of the nature of the discussion up to speculation. Wyatt, Katz and Kim (2000) argued that political discussion should include common talk that people perform in their families, workplaces and other public places. Their data suggested that national affairs, international affairs, state and local affairs and the economy were discussed frequently at home and at work and that these discussions figured significantly in the development of political opinion and participation in the political process (Wyatt, Katz \& Kim, 2000).

Researchers have speculated that interpersonal discussion with dissimilar others might produce confusion, thus interfering with the effects of the media (Feldman $\&$ Price, 2008). Some researchers (Huckfeldt \& Sprague, 1995; Mutz \& Martin, 2001) have attempted to look more closely at the nature of disagreement in interpersonal discussion and whether communicating with heterogenous others changes the outcomes. Mutz and Martin (2001) found that exposure to disagreement creates ambivalence and uncertainty when it comes to political candidates and issues and also hinders political participation. In converse, Kwak, Williams, Wang and Lee (2005) found that network heterogeneity was a significant predictor of political knowledge and political participation in their

\footnotetext{
${ }^{4}$ Only one of Eveland and Scheufele's tests supported their original theory of differential gains, in which interpersonal discussion actually reinforced the learning connected to media.
} 
phone survey of 292 adult residents of Ann Arbor, Michigan. In addition they found that network size, discussion frequency, discussion attention (the degree of attention respondents claimed to have paid to political discussions) and integrative discussion (a variable that tapped into the extent respondents referred to information from mass media sources in their discussions) were significantly predictive of political knowledge and political participation. When looking at interactive effects, political participation was predicted by a combination of these variables but political knowledge was not (Kwak, Williams, Wang \& Lee, 2005).

Feldman and Price (2008) built on previous research by choosing three different media outlets - newspapers, television news and candidate debates - and looking at interactive effects with, not only interpersonal discussion with like-minded individuals, but with interpersonal discussion between individuals who disagreed, theorizing that political disagreement should enhance political issue learning. ${ }^{5}$ Their findings indicate that only television news had any significant impact on background knowledge about the candidate. None of the three forms of media had any significant impact on issue knowledge. When combined with frequency of interpersonal discussion, the only significance was found in those who had extremely high levels of conversation. In contrast to their theory, frequent interpersonal discussions were found to be significantly correlated with lower levels of issue and candidate background knowledge (Feldman \& Price, 2008).

When frequency of interpersonal discussion was combined with disagreement, the

\footnotetext{
${ }^{5}$ The unique context of their study was in the 2000 presidential primary campaign, however, and the authors themselves admit that looking at primary rather than general election activities may restrict the generalizability of their findings.
} 
only significance was found in levels of issue knowledge ${ }^{6}$. Adding disagreement resulted in lower levels of issue knowledge but not background knowledge, which confirms the speculation of Eveland and Scheufele (Feldman \& Price, 2008) and the findings of Mutz and Martin (2001). Feldman and Price (2008) concluded that media play only a minor role in communicating overall candidate knowledge in presidential primary campaigns and that television news is the sole significant predictor of background knowledge.

The Role of the Internet

One form of media often ignored when examining political knowledge is the growing role of the Internet as a source of information. Early research into the role of the Internet in campaigning has found less impact on voters' knowledge about candidates than might be expected. After controlling for more traditional media campaign exposure to television and newspaper coverage, Internet usage was not shown to significantly affect levels of knowledge about candidates (Weaver \& Drew, 2001). But since the publication of this research, the use of the Internet for campaigning in presidential elections has expanded substantially.

Candidate web sites, e-mail, on-line fundraising, blogs, and social networking sites such as YouTube and MySpace have changed the dynamic of the last three presidential campaigns. According to poll results reported by Gueorguieva (2008), about $15 \%$ of all American adults said the Internet was their primary source of campaign news during the 2006 elections and almost $18 \%$ said they relied on the Internet as their primary source of information in the 2004 presidential campaign cycle. ${ }^{7}$ During the 2006

\footnotetext{
${ }^{6}$ Lenart(1994) suggested that issue knowledge would be affected because it is more prone to dispute than background knowledge.

${ }^{7}$ This is up from $7 \%$ who reported the Internet as their primary source of campaign information during the midterm election of 2002 (Gueorguieva, 2008).
} 
elections, $25 \%$ of Americans said they did get some information online and $10 \%$ said they exchanged e-mails about the candidates. Overall, almost one-third of all adult Americans, more than 60 million people, reported that they gathered information and exchanged views via e-mail during the 2006 presidential campaign season (Gueorguieva, 2008). It is also reported that $12 \%$ of Americans reported reading political blogs at least a few times a month during the 2004 elections (Gueorguieva, 2008). Many assume that the Internet is the purview of primarily younger adults, but demographic data from YouTube and MySpace show that over half of YouTube and MySpace users are over 35 (Gueorguieva, 2008). ${ }^{8}$ A more in-depth study of MySpace demographics, showed that $85 \%$ of users were of voting age and that they were three times more likely to contact a public official or candidate online, $42 \%$ more likely to watch politically related online video, $35 \%$ more likely to research politics online and $44 \%$ more likely to listen to political audio online (Gueorguieva, 2008).

\section{Previous Studies}

Studies examining these variables have found varying results due in part to the type of election examined. Some studies have looked at primaries (Feldman \& Price, 2008), some have studied senatorial or gubernatorial elections (Brians \& Wattenberg, 1996; Craig, Kane \& Gainous, 2005) and most have used varying national election survey results over a wide space of years. These varying research findings about the role of media in the form of newspapers, television news, and Internet use still raise the question of the effects of the media, coupled with interpersonal discussion, on individuals' levels of knowledge about candidates. One generalization about existing

\footnotetext{
${ }^{8}$ Several different studies between May and August 2006 found between $48 \%$ and $65 \%$ of YouTube users were 35 to 64 years old, while $51.6 \%$ of MySpace users were 35 or older (Gueorguieva, 2008).
} 
research is that the main focus is on the direct influence of media sources on vote choice and voter turnout (Cho, 2008). There is a need to broaden this focus to include the influence of media and interpersonal discussion on the "reasoning and beliefs that lead in turn to informed decisions that reflect [citizens'] needs and interests" (Cho, 2008, p. 424). With that in mind, this study will examine citizens' knowledge about candidates' political positions and background, in addition to whether or not they actually voted in the election. This research will add to the understanding of the impact that various forms of media, including the Internet, and interpersonal conversations have on knowledge about candidates and choices to vote during presidential campaigns. 


\section{CHAPTER THREE}

\section{METHODS}

\section{Hypotheses and Research Questions}

This study attempts to identify and test a simple model for the interaction of media use and interpersonal discussion in the 2000 and 2004 presidential elections in order to answer the questions still surrounding these variables. In addition, this model provides a starting point for examining other types of elections in light of these independent variables.

Media Use (Newspaper,

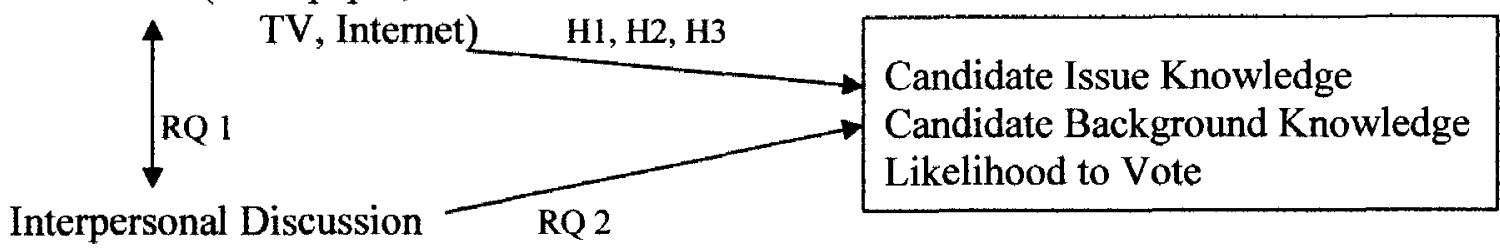

Figure 1. Model of media use and interpersonal communication impacting voter knowledge and likelihood to vote

The model above illustrates the expected relationships between various forms of media use, interpersonal discussion, candidate issue knowledge, candidate background knowledge and likelihood to vote, which lead to the following hypotheses and research questions: 
Hypothesis 1: Media use (newspaper reading, television news viewing and Internet use) and interpersonal discussion will be positively associated with candidate issue knowledge.

Hypothesis 2: Media use (newspaper reading, television news viewing and Internet use) and interpersonal discussion will be positively associated with candidate background knowledge.

Hypothesis 3: Media use (newspaper reading, television news viewing and Internet use) and interpersonal discussion will be positively associated with likelihood to vote.

Research Question 1: What form of media use (newspaper reading, television news viewing or Internet use) is most associated with the likelihood of having interpersonal political discussion?

Research Question 2: Does interpersonal discussion add significantly to respondents' candidate issue knowledge, candidate background knowledge or likelihood to vote?

Sample and Source of Data

The source of data for this project is the National Annenberg Election Surveys (NAES) of the Electronic Dialogue Project (EDP) of the Annenberg School at the University of Pennsylvania. The NAES data were available for two full presidential election cycles -2000 and 2004. These surveys are the "largest academic public opinion studies of the American electorate ever conducted within a campaign cycle" (Annenberg Public Policy Center, 2008). The data were collected through national telephone surveys using a Rolling Cross Sectional Survey technique. The interview respondents are adults 
over the age of $18 .^{9}$ Interviewers asked respondents about their beliefs, attitudes, intentions and behavior relevant to the 2000 and 2004 presidential campaigns prior to the election and then followed-up with a shorter survey of the same respondents after the election. A total of 79,458 respondents participated in 2000 and 90,134 in 2004 (Annenberg Public Policy Center, 2008).

Respondents for the 2000 NAES were interviewed from mid-December 1999, just before the height of the presidential primary election season, through mid-January 2001 , after the dispute over whether George W. Bush or Al Gore won the election and just before Bush's inauguration (Annenberg Policy Center, 2008). The respondents in the 2000 survey were $56 \%$ female and the average educational level fell between "some college, no degree" and "associate's or two-year college degree." The average age of respondents was 54.91 and the mean household income was $\$ 35,000$ to $\$ 50,000$ (NAES, 2000).

For the 2004 NAES data, respondents were initially interviewed in the weeks leading up to the 2004 presidential election (July 15, 2004, to November 1, 2004) and reinterviewed in the weeks following the election (November 4, 2004, to December 28, 2004). The mean age for the 2004 respondents was 50.77 years and $55.2 \%$ were female. The educational level in the 2004 survey also fell between "some college, no degree" and “associate's or two-year college degree." Finally the mean household income was also $\$ 35,000$ to $\$ 50,000$ (Holbert, LaMarre, \& Ladreville, 2009).

\footnotetext{
${ }^{9}$ The sample is drawn from a nationally representative panel of survey respondents maintained by the Knowledge Networks, Inc. of Menlo Park, California. The Knowledge Networks panel is made up of tens of thousands of households selected through random-digit dialing (Feldman \& Price, 2008).
} 
Media Use

There are four independent variables in this study - newspaper reading, television news viewing, Internet use and interpersonal discussion. (Interpersonal discussion becomes a dependent variable for the first research question.) Originally, the intention was to create an index for reflecting overall media use, composed of the three separate media use variables of newspaper reading, television news viewing and Internet use. However, the reliability on the overall media use index was very low $(\alpha=.34)$. This is not surprising as choices of media use are made discreetly and therefore, it would make sense that those who read newspapers may rely less on television news or Internet sources and vice versa. ${ }^{10}$ Therefore, it was decided not to create an overall media use index for this study.

Looking at the various forms of media use, the first, newspaper reading, was measured by one item from the 2000 and 2004 NAES data: how much attention did the respondent pay to political news in the newspaper in the past week. The second form of media use, television news viewing, was measured by two items from the 2000 NAES data: (1) Respondent paid attention to political news on network TV in the past week and (2) Respondent paid attention to political news on cable TV in the past week. These two variables were collapsed into one variable in the 2004 NAES data: respondent paid attention to political news on network or cable TV in the past week. The third form of media use and the one that is examined for the first time in this study, Internet involvement, was measured by one item from the 2000 NAES data: Paid attention to online information about the presidential campaign. Two items from the 2004 NAES

${ }^{10}$ Cho (2008) found similar results when looking at national news use, local news use and Internet use of political information. The forms of media use were treated in parallel form in Cho's study, and though closely interrelated, each of the forms were found to have different predictors (p. 444). 
data were used to measure Internet involvement: (1) Respondent discussed politics online in the past week and (2) Respondent accessed political information online in the past week.

\section{Interpersonal Discussion}

The final independent variable is interpersonal discussion. Interpersonal discussion was measured by one item from the 2000 NAES data: Discussed politics with family or friends in the presidential campaign. In the 2004 NAES data, this variable was measured by two variables: (1) Discussed politics with family or friends in past week and (2) Discussed politics with others at work in the past week.

There are three dependent variables in the present study: candidate issue knowledge, candidate background knowledge, and likelihood of voting. The first two variables were necessarily measured using different items for each election as the candidates changed in the 2000 and 2004 elections.

\section{Candidate Issue Knowledge}

First, candidate issue knowledge was measured by twelve items from the 2000 NAES data set: (1) Bush or Gore favors biggest tax cut, (2) Bush or Gore favors using Medicare surplus to cut taxes, (3) Bush or Gore favors paying down debt most, (4) Bush or Gore favors doubling per-child tax deduction, (5) Bush or Gore favors investing Social Security in stock market, (6) Bush or Gore favors school vouchers, (7) Bush or Gore favors universal health care for children, (8) Bush or Gore favors right to sue HMOs, (9) Bush or Gore favors restricting abortion, (10) Bush or Gore favors handgun licenses, and (11) Bush or Gore favors soft money ban.

In the 2004 election, candidate issue knowledge was measured by eight items 
from the 2004 NAES data set: (1) Bush or Kerry favors making Bush tax cuts permanent, (2) Bush or Kerry favors making union organizing easier, (3) Bush or Kerry favors government health insurance for children and workers, (4) Bush or Kerry favors Medicare Prescription Law, (5) Bush or Kerry favors Social Security in stock market, (6) Bush or Kerry favors Patriot Act, (7) Bush or Kerry favors stem cell funding, and (8) Bush or Kerry favors assault weapons ban.

\section{Candidate Background Knowledge}

The second dependent variable is candidate background knowledge. Candidate background knowledge was measured by five items from the 2000 NAES data set: (1) Bush or Gore is governor, (2) Bush or Gore is son of senator, (3) Bush or Gore served in Vietnam, (4) Bush or Gore spoke at Bob Jones University, and (5) Bush or Gore owned a baseball team. Candidate background knowledge was measured by one item from the 2004 NAES data set: Bush or Kerry is a former prosecutor.

\section{Likelihood to Vote}

The third dependent variable, likelihood to vote, was measured by one item of self-reported voting in the election from the 2000 and 2004 NAES data follow-up surveys: Respondent voted in the general election.

\section{Control Variables}

Several control variables are included in this study. Gender and race are basic demographic variables. Educational level is included as a control variable because educational level is wellknown to influence likelihood of voting and could influence overall political knowledge (Cho, 2008, Craig, Kane \& Gainous, 2005). Finally, the respondent's political involvement was measured using four items from the 2000 and 
2004 NAES data set to create a political involvement index: (1) Attended a meeting for presidential candidate in the fall campaign, (2) Did other work for a presidential candidate in the fall campaign, (3) Gave money to a presidential candidate in the fall campaign, and (4) Displayed sign for presidential candidate in fall campaign. Initially there was a measure of strength of party identification or partisanship included in this measure, but reliability analysis showed that it did not correlate reliably with the other variables related to political involvement. Partisanship determines political perceptions, attitudes and behaviors and can be a strong influence on vote choice. It is argued that "the psychological influence of party seems as great now as at any time since the Second World War" (Johnston, 2006, p. 343). "When a voter brings this type of psychological baggage to a mediated political communication experience, it can determine the strength and/or direction of a media effect" (Holbert, LaMarre \& Landreville, 2009). Therefore, political involvement is included as a control variable because it will determine whether those who are engaged in media use and interpersonal discussion are only doing so because they are politically active and would be likely to vote and to have higher levels of candidate knowledge even if they didn't engage in these communication activities.

\section{Research Design}

Once data items important for this study were parsed from the overall data sets, each was re-coded to a consistent format. An index of each variable was created and standardized so that variables could be easily compared. After the indexes were compiled, correlation matrices of all variables were created for comparisons. The three hypotheses above were answered with these simple correlation results. The first research question can likewise be answered with simple correlation analysis. 
Second, a regression analysis was used to examine the degree of impact of each independent variable on each dependent variable and to test the fit of the overall model. Regression analysis was used to determine the effect of each of the independent variables on the dependent variables while holding constant the effect of other independent variables in each model. The second research question required regression to determine the significant additional impact of interpersonal discussion on the dependent variables. Linear regression was used to test models in two ways: (1) to see how the overall model fits the data and (2) to see how separate components of the model perform. Regression (and the $\mathrm{R}^{2}$ measure it produces) allows for determining not only the relationship of two variables, but also what percentage of the dependent variable is explained by the independent variables (Kahane, 2001). Therefore, linear regression is the best method of analyzing this data to answer the research question and support the hypotheses of the overall model proposed.

Binary logistic regression was used to answer the research question related to likelihood to vote. Since likelihood to vote is a nominal level, dichotomous dependent variable, it is not appropriate to use linear regression. After the logistic regression was completed, simple crosstabs were also calculated to examine the relationship of interpersonal communication and likelihood to vote in more detail. SPSS was used to perform all of the mathematical analyses. 


\section{CHAPTER FOUR}

\section{RESULTS - RELATIONSHIPS AMONG VARIABLES}

\section{Descriptive Statistics}

The model to be tested for this study requires testing three hypotheses and answering two research questions. Before beginning an analysis of the data, it is important to look at basic descriptive statistics for each of the independent and dependent variables included in the study. The descriptive statistics for the variables in the 2000 election are found in Table 1. Table 2 contains descriptive statistics for the 2004 election. Further tables reporting frequencies are located in Appendix B. (The 2000 Dataset is missing a large amount of data for many items and so the number of respondents for each variable varies widely.)

In presenting the results, I discuss the 2000 data first, then the 2004 data and then compare the two. Not surprisingly, a quick look at the means for each of the types of media use (newspaper reading, television news viewing and internet use) shows that in the 2000 data television news viewing is more prevalent than newspaper reading as a means of gathering political information. The variables are coded from $0=$ "none" to $3=$ "a great deal." (The complete codebook for both the 2000 and 2004 data is found in Appendix A.) With this means of measurement in mind, television news viewing is most prevalent $(M=1.71, S D=.89$, between "some" and "not too much"), with newspaper reading coming in second $(M=1.51, S D=1.06)$. Interpersonal discussion is measured 
differently, based on the number of times per month the respondent has engaged in the activity. Internet use is measured in the same way as interpersonal discussion, which makes these two variables comparable. Interpersonal discussion $(M=1.35, S D=.61)$ is more prevalent as a means of gathering and sharing political information than is Internet use $(M=1.01, S D=.83)$.

In the 2000 data, candidate issue knowledge and candidate background knowledge are measured on a scale from 0 to 1 , with 1 being complete knowledge. Another way of looking at this is to think about it in terms of percentage of knowledge. For instance, the mean found for candidate issue knowledge $(M=.19, S D=.25)$ indicates that respondents knew an average of 19 percent of the questions used to assess their knowledge level. (See Chapter Three or the codebook in Appendix A for the list of items used to measure candidate issue knowledge.) Likewise, for candidate background knowledge, the variable is measured on a 0 to 1 scale, with 1 being complete knowledge. Candidate background knowledge $(M=.29, S D=.26)$ is higher overall than issue knowledge.

The 2004 respondents are largely similar to those in the 2000 data with similar gender, race and educational demographics. ${ }^{11}$ Television and newspaper media use are measured by the same scale as in the 2000 data. As shown in Table 3 , television news viewing is most prevalent $(M=2.58, S D=1.36)$ falling between "some" and "quite a bit." Newspaper reading $(M=2.27, S D=1.44)$ likewise falls between "some" and "quite a bit." In the 2004 survey, interpersonal communication and Internet use is measured by the number of days per week the respondent engages in the activity. Comparison of the two shows that interpersonal discussion $(M=1.82$ days per week, $S D=1.84)$ is more

\footnotetext{
${ }^{11}$ See pp. 20-21 to see a more complete discussion of the demographic make-up of respondents in both studies.
} 
prevalent than Internet use $(M=.84$ days per week, $S D=1.53)$. There are some differences in use of media between the 2000 and 2004 years. First, reports of frequency of television news viewing and newspaper reading both increased in the 2004 findings. Differences in the items measuring interpersonal discussion and Internet use between the two datasets make it impossible to clearly compare them.

In 2004, candidate issue knowledge increased slightly $(M=.21, S D=.22)$, as did candidate background knowledge $(M=.34, S D=.47) .^{12}$

Appendix B, Table 13, describes frequencies for demographic characteristics of respondents included in the 2000 election statistics reported in this study. The majority of respondents voted, 84 percent, as compared to 16 percent who did not. A majority of the respondents were female, 56 percent, compared to 45 percent males. Also a large majority were white, 87 percent, compared to only 13 percent of other races. Last, the majority of respondents were Republicans, 59 percent, compared to 41 percent reported Democrats. (Independents are not reported in the 2000 NAES.)

Appendix B, Table 14, describes frequencies for demographic characteristics of respondents in the 2004 election. Characteristics of the respondents were largely the same as those in the 2000 election, with the exception of party identification. Respondents in the 2004 election were more evenly split across party lines, 37 percent reported as Republicans, 36 percent Democrats, and 27 percent reported they were Independents. (Independent was added as a response after the 2000 NAES.) The majority voted, 90 percent. The majority were again female, 55 percent. The large majority were again white, 89 percent, compared to only 11 percent of other races. A description of

${ }^{12}$ Candidate background knowledge was measured by only one item on the 2004 survey. Other items were included on the survey, but the response rate was so low or non-existent that only one item could reliably be used for measurement. 
demographic characteristics of respondents to both NAES surveys overall is included in Chapter Three.

Hypothesis One: Candidate Issue Knowledge

Once I examined the variables for basic descriptive features, then I could analyze the data to test the three proposed hypotheses. The three hypotheses address how media use relates to level of knowledge about political issues and background of the candidate, as well as how likely the individual is to actually vote. In order to examine these relationships, a Pearson correlation matrix was created using SPSS to see the strength of connection between each pair of variables. The resulting correlation tables are found in Tables 3 and 4.

Hypothesis One states: Media use (newspaper reading, television news viewing and Internet use) and interpersonal discussion will be positively associated with candidate issue knowledge. Based on what is known about the relationship between media use and political knowledge, it would seem to follow that the more often individuals engage in reading, viewing or discussing political topics, the more knowledgeable they would be about presidential candidates' positions on issues.

In the 2000 NAES data, the correlation between newspaper reading and candidate issue knowledge is significant and positive, as is television news viewing and interpersonal discussion. Newspaper reading has the strongest correlation, $r(6486)=.10, p<.01$, with interpersonal discussion, $r(6423)=.084$, $p<.01$, and television news viewing closely following, $r(6454)=.083, p<.01^{13}$.

However, Internet use, though it has a positive correlation with candidate issue

${ }^{13}$ Sample size of the overall survey is high, but many participants fell out on individual items due to filter questions so there are varying sample sizes for each item. The number of respondents on each item is still relatively high, but due to the use of one item to measure many variables correlations are low. 
knowledge, $r(4200)=.023, p=.13$, is not significantly correlated with candidate issue knowledge. There may be many reasons for this lack of connection between Internet use and knowledge about candidate issues. In the 2000 presidential election, the Internet was just beginning to be used as a political and social networking tool. Candidates were not yet aware of the impact that the online community might exert in sharing information about candidates' issue positions. More efforts to include the Internet as a means of disseminating campaign information were made in the 2004 election (Gueorguieva, 2008; Rice, 2003).

The 2004 data do support the significant correlations postulated in hypothesis one. Newspaper reading, television news viewing, Internet use and interpersonal discussion are all positively and significantly associated with respondents' knowledge about candidates' positions on the issues. Here, the interesting finding is that Internet use actually has a stronger correlation, $r(8662)$ $=.091, p<.01$, than either newspaper reading, $r(8662)=.077, p<.01$, or television news viewing, $r(8662)=.086, p<.01$, with candidate issue knowledge. Interpersonal discussion is more strongly correlated with candidate issue knowledge than any form of media use, $r(8662)=.102, p<.01$.

\section{Hypothesis Two: Candidate Background Knowledge}

Hypothesis Two states: Media use (newspaper reading, television news viewing and Internet use) and interpersonal discussion will be positively associated with candidate background knowledge. Again, the expectation was that exposure to media in the forms of newspapers, television and Internet sites would be positively associated with the level of knowledge about the candidates' 
background. The 2000 election data confirm this hypothesis for all forms of media use. Newspaper reading, television news, Internet use and interpersonal discussion are all positively and significantly correlated with candidate background knowledge. Newspaper reading has the highest correlation, $r(6486)=$ $.167, p<.01$, with interpersonal discussion, $r(6482)=.122, p<.01$, and television news viewing, $r(6454)=.102, p<.01$, following. Internet use is significantly correlated with candidate background knowledge, but at a lower level than other forms of gaining and sharing political knowledge, $r(4200)=.057, p<.01$.

The same findings held for the 2004 presidential campaign. Here, however, the correlations are much lower though still statistically significant. This could be due to the fact that candidate background knowledge was measured by only one item on the 2004 survey. Internet use actually has the highest correlation to candidate background knowledge $r(8662)=.082, p<.01$, while television news viewing, $r(8662)=.076, p<$ .01 , interpersonal discussion, $r(8662)=.067, p<.01$, and then newspaper reading, $r(8662)=.033, p<.01$, follow

Hypothesis Three: Likelihood to Vote

Hypothesis Three states: Media use (newspaper reading, television news viewing and Internet use) and interpersonal discussion will be positively associated with likelihood to vote. Higher education levels have been clearly associated with likelihood to vote. Therefore, it would seem to follow that active engagement in seeking and sharing information about the presidential campaign through media and interpersonal discussion should be associated with actually voting. 
Likelihood to vote is measured using a "yes" or "no" item asking whether the respondent did vote after the election was over. In 2000, all forms of media use and interpersonal discussion are positively associated with the likelihood that the respondent did actually vote. Newspaper reading has the strongest correlation, $r(6486)=.215, p<$ .01 , followed by television news viewing, $r(6454)=.186, p<.01$, then interpersonal discussion, $r(6482)=.165, p<.01$, and then Internet use, $r(4200)=.065, p<.01$. Likewise, in 2004, all forms of media use and interpersonal discussion are positively associated with likelihood to vote. The 2004 data hold the same pattern as the 2000 data with newspaper reading having the strongest correlation, $r(8662)=.191, p<.01$, followed by television news viewing, $r(8662)=.181, p<.01$, then interpersonal discussion, $r(8662)=.107, p<.01$, and finally Internet use, $r(8662)=.093, p<.01$. Research Question One: Media Use and Interpersonal Discussion

The first Research Question posed was: What form of media use (newspaper reading, television news viewing or internet use) is most associated with the likelihood of having interpersonal political discussion? In other words, since different forms of media use are distinct and often predicted by different factors (Cho, 2008), are certain media more related to interpersonal discussion than others?

Correlation matrices for the 2000 and 2004 election data were used to answer this question. In 2000 , interpersonal discussion is most strongly correlated with television news viewing, $r(6454)=.246, p<.01$, followed by newspaper reading, $r(6486)=.196, p$ $<.01$, and finally Internet use, $r(4200)=.105, p<.01$. In 2004 , Internet use is most strongly correlated with interpersonal discussion, $r(8662)=.307, p<.01$, followed by 
television news viewing, $r(8662)=.183, p<.01$, and newspaper reading $r(8662)=.176$, $p<.01$. Perhaps, this is one result of the increased role of the Internet as not only an informational tool, but also as a networking tool for sharing political information. This is an area for future research as the role of the Internet in presidential campaigns continues to grow.

Comparisons in 2000 and 2004 Correlations

A comparison of the correlations from 2000 and 2004 data shows some other interesting findings. First, the correlation of Internet use to all of the other variables increased from 2000 to 2004 . For instance, Internet use was not significantly correlated with candidate issue knowledge in $2000, r(4200)=.023, p=.13$, but was significantly correlated to that variable in $2004, r(8662)=.091, p<.01$. In addition, the relationship between Internet use and all other variables (newspaper reading, television news viewing, interpersonal discussion, candidate background knowledge, and likelihood to vote) had stronger correlations in 2004 than in 2000.

More precise means of measuring how respondents are using the Internet to glean and share political information may account for this change in part. As mentioned previously, items measuring Internet use were different in each data set. In 2000 , only one item measured on a per month basis, "paid attention to online information about the presidential campaign," was available. In 2004 , two items measured by number of days per week "respondent accessed political information online in the past week" and "respondent discussed politics online in the past week" provide more detailed information about Internet use. (See Appendix A for details of how each variable was measured in each dataset.) This increase could also be explained through the 
proliferation of the Internet as a tool for presidential campaigns to get out their message, as well as an increase in the number of individuals who are using the Internet as a source of political information and as a discussion forum (Gueorguieva, 2008).

Second, an examination of the relationship between candidate issue knowledge, candidate background knowledge and likelihood to vote provides some interesting findings. Although, all three are significantly correlated in both datasets, it is interesting to note that in the 2000 data, candidate background knowledge is more strongly correlated with likelihood to vote, $\mathrm{r}(6506)=.151, p<.01$, than is candidate issue knowledge, $r(6506)=.098, p<.01$. In the 2004 election data, the reverse is true. Candidate issue knowledge is more strongly correlated with likelihood to vote, $r(8662)=$ $.123, p<.01$, than is candidate background knowledge, $r(8662)=.077, p<.01$. This provides an interesting basis for future study. Did having a sitting president running for reelection in 2004 make candidate background knowledge more common knowledge and thus less of an influence on whether or not a person voted? It has been surmised that many who vote do so without clear understandings of the policy positions of the candidates and how these policies will affect them directly (Frank, 2004). Does this understanding of policy and knowledge of candidates' stands on issues change depending on the overall political climate of the election? These are interesting questions based on the preliminary findings and correlations of the variables in the 2000 and 2004 NAES datasets. Chapter Six provides expanded discussion on questions for further study. 


\section{CHAPTER FIVE \\ RESULTS - ROLE OF INTERPERSONAL COMMUNICATION}

From the beginning of study about communication effects on the audience, one of the leading questions has been how the media interact with individuals to increase their knowledge of political information and influence their political actions. Suggestions of the 'two-step' flow are that media influence certain opinion leaders, who in turn discuss with and influence other people in the population (Lowery \& DeFleur, 1995; Weaver \& Drew, 2001; Wyatt, Katz \& Kim, 2000). But how much does the role of interpersonal discussion among various members of the citizenry play in political knowledge, decisions and actions? There is still much to explore related to this question and therefore, this study asked Research Question Two: Does interpersonal discussion add significantly to respondents' candidate issue knowledge, candidate background knowledge or likelihood to vote? In order to answer this question, regression was used to see how several factors predict levels of knowledge or likelihood to vote (see discussion of this method in Chapter Three).

\section{Interpersonal Communication and Candidate Issue Knowledge}

First, the results related to candidate issue knowledge were explored. The results of the linear regression of the 2000 presidential election are found in Table 5. The variables found to be significant predictors of levels of candidate issue knowledge are gender $(\beta=-.063, S E=.008, p<.01)$, race $(\beta=-.038, S E=.006, p<.05)$, educational 
level $(\beta=.097, S E=.002, p<.01)$, newspaper reading $(\beta=.045, S E=.004, p<.01)$ and interpersonal discussion $(\beta=.033, S E=.007, p<.05)$. Party identification, political involvement, television news viewing and Internet use were not significant predictors of level of candidate issue knowledge. The negative relationship between gender and candidate issue knowledge indicates that males have a higher level of candidate issue knowledge than do females in the study. Likewise, the negative relationship between race and candidate issue knowledge indicates that whites have a higher level of knowledge than do other races. The negative relationship between Internet use and candidate issue knowledge, though not statistically significant, does indicate that increased Internet use actually resulted in lower levels of candidate issue knowledge.

The regression results of the 2004 presidential election are reported in Table 6. Again, gender is a significant predictor of candidate issue knowledge $(\beta=-.075, S E=$ $.005, p<.01)$, as is race $(\beta=.030, S E=.003, p<.01)$ and educational level $(\beta=.105$, $S E=.001, p<.01)$. Also significant are political involvement $(\beta=.264, S E=.014, p<$ $.01)$, television news viewing $(\beta=.046, S E=.002, p<.01)$, and interpersonal discussion $(\beta=.026, S E=.001, p<.05)$. The relationships between gender and candidate issue knowledge and race and candidate issue knowledge are once again negative, indicating men and whites have higher levels of knowledge about candidates' issue positions. Newspaper reading is not significant in the 2004 election and neither is Internet use. In 2004 , television news viewing is significant while newspaper reading is not. Internet use is not a significant predictor of candidate issue knowledge in either year's election.

To answer the first element of the research question, interpersonal discussion does significantly predict levels of candidate issue knowledge in the 2000 presidential election 
and in the 2004 presidential election. The more respondents report being involved in interpersonal discussion, the higher their level of candidate issue knowledge. This finding indicates that interpersonal discussion does add significantly to the level of candidate issue knowledge.

\section{Interpersonal Communication and Candidate Background Knowledge}

The second part of the research question asks if interpersonal discussion adds significantly to the level of knowledge about candidates' backgrounds during the 2000 and 2004 presidential elections. The regression results concerning candidate background knowledge in the 2000 election are found in Table 7 . Significant predictors of candidate background knowledge are gender $(\beta=-.072, S E=.008, p<.01)$, race $(\beta=-.058, S E=$ $.005, p<.01)$, education level $(\beta=.142, S E=.002, p<.01)$, party identification $(\beta=-$ $.037, S E=.006, p<.05)$, political involvement $(\beta=.046, S E=.021, p<.01)$, newspaper reading $(\beta=.101, S E=.004, p<.01)$, and interpersonal discussion $(\beta=.049, S E=.007$, $p<.01)$. The negative relationships between gender and race and background knowledge, again indicate that men and whites tend to have higher levels of knowledge about candidates' backgrounds. The negative relationship between party identification and candidate background knowledge indicates that Republicans tend to have higher levels of knowledge about candidates' backgrounds. Television news viewing and Internet use are not significant predictors of levels of candidate background knowledge. Interpersonal discussion, the variable specifically examined in this research question, is significant.

The 2004 presidential election is presented in Table 8 . In this case, candidate background knowledge was measured by a single item on the survey asking whether 
candidate Bush or Kerry had previously been a prosecutor. Gender $(\beta=-.026, S E=.010$, $p=.01)$, education level $(\beta=.090, S E=.002, p<.01)$, party identification $(\beta=.021, S E$ $=.005, p=.05)$, political involvement $(\beta=.167, S E=.031, p<.01)$, television news viewing $(\beta=.057, S E=.004, p<.01)$ and Internet use $(\beta=.029, S E=.004, p=.01)$ are all significant predictors of knowing about the candidates' background. This is the first finding that Internet use is a significant predictor of a dependent variable. Those who use the Internet more often to access and discuss political information related to the campaign (see Appendix A for the codebook reporting exact items used to measure this item) tend to know this fact about the candidates' background.

To answer the research question, interpersonal discussion does significantly predict candidate background knowledge in the 2000 election, but it does not significantly predict the level of background knowledge in the 2004 election. So, for this dependent variable, the significance of interpersonal discussion varies and therefore would require additional years of data to determine.

Interpersonal Communication and Likelihood to Vote

The final element of the second research question is how and if interpersonal discussion influences the likelihood of respondents to vote. Because likelihood to vote is a dichotomous nominal level variable, linear regression was not an option. Logistic regression was used to examine this part of the question. Race $(B=-.233, S E=.057, p<$ $.01)$, education level $(B=.219, S E=.023, p<.01)$, political involvement $(B=2.448$, $S E$ $=.453, p<.01)$, newspaper reading $(B=.367, S E=.049, p<.01)$, television news viewing $(B=.286, S E=.058, p<.01)$, and interpersonal discussion $(B=.213, S E=$ $.084, p=.01)$ are significant predictors of the likelihood to vote in the 2000 election. 
Gender, party identification and Internet use are not significant predictors. Table 9 reports these findings.

In the 2004 election, the only factor not significant in predicting likelihood to vote was Internet use. Gender $(B=.285, S E=.078, p<.01)$, race $(B=-.212, S E=.037, p<$ $.01)$, educational level $(B=.282, S E=.019, p<.01)$, party identification $(B=-.292, S E=$ $.039, p<.01)$, political involvement $(B=3.196, S E=.566, p<.01)$, newspaper reading $(B=.276, S E=.028, p<.01)$, television news viewing $(B=.269, S E=.028, p<.01)$ and interpersonal discussion $(B=.064, S E=.025, p=.01)$ are all significant predictors of likelihood to vote. Race has a negative relationship with likelihood to vote, which indicates that whites were more likely to vote than those of other races. Likewise, in 2004, party identification has a negative relationship with likelihood to vote, which indicates that Republicans were more likely to vote in this election. Table 10 displays the complete findings for the 2004 election.

Crosstabs were compiled from the data to examine the relationship between interpersonal communication and voting in more detail. The 2000 election results are reported in Table 11. Results show that 88 percent of those who responded that they discussed the presidential campaigns with family, friends or co-workers at least a few times a month voted. Of those who reported that they discussed the presidential campaigns less often than a few times a month, 84 percent voted. Of those who reported that they never discussed the presidential campaigns, only 58 percent voted.

In 2004, crosstabs of the data comparing interpersonal communication with likelihood to vote indicate that 93 percent of those who reported talking to another about the presidential election more than five days a week voted. Those who reported 
discussing the presidential campaigns with another four to five days a week were the most likely to vote (95 percent). Of those who discussed the campaigns three to four days a week, 94 percent voted; and of those who discussed the campaigns two days a week or less, 91 percent voted. Those who reported never discussing the campaigns were the least likely to vote ( 84 percent voted). Crosstabs for the 2004 election are reported in Table 12.

In answer to the research question, interpersonal discussion does significantly predict likelihood to vote in both election years. Therefore, the findings for this research question are that interpersonal discussion does add significantly to candidate issue knowledge in both election years, adds significantly to candidate background knowledge in the 2000 election year and adds significantly to likelihood to vote in both election years. Such a finding reinforces previous literature in pointing out not just the importance of media when looking at how political information is shared, but also the role of individuals discussing candidates and issues with each other.

\section{Overall Model Fit}

The regression results for knowledge about candidates' positions on issues for 2000 (Table 5) and 2004 (Table 6) reflect that this model does predict the political learnig outcomes at a relatively low level. The overall fit for 2000 is $R^{2}=.03$ and for 2004 is higher, at $R^{2}=.10$. These outcomes mirror to a lesser degree the findings of Feldman and Price (2008) in their examination of the 2000 primary election. Their model for predicting candidate issue knowledge was $R^{2}=.18$ (p. 75). Their model included television debates, rather than Internet use, and added levels of disagreement when engaging in interpersonal communication. Otherwise their list of independent variables 
provided the general model that was tested in this study. However, as Feldman and Price (2008, p. 80) point out "the primary campaign context...may provide for quite a different environment than the general election campaign and thus restrict the generalizability of our results."

The overall model fit for candidate background knowledge in this study was similarly low. Table 7 reports the overall fit for the 2000 election at $R^{2}=.06$. Table 8 reports the overall fit for the 2004 election at $R^{2}=.05$. Feldman and Price (2008) found a higher overall fit in the 2000 presidential primary election, $R^{2}=.29$, with the same caveats as described above.

The overall model fit was much stronger for likelihood to vote than for candidate issue or background knowledge. In the 2000 presidential election (Table 9) the Nagelkerke $R^{2}=.16$ and for the 2004 election (Table 10), Nagelkerke $R^{2}=.22$. The model predicted correctly the likelihood to vote 86.8 percent of the time in the 2000 election and 90 percent of the time in the 2004 election. By looking at the overall fit of the model for these three outcomes, it is possible to see that although media use, interpersonal discussion and demographic variables explain some level of the outcomes, there are many other variables at work here. 


\section{CHAPTER SIX}

\section{DISCUSSION}

\section{Overall Findings}

Beginning this study, I expected the results to show that media use in all three forms (newspaper reading, television viewing and Internet use) would be positively and significantly associated with candidate issue knowledge, candidate background knowledge and likelihood to vote. In summary, the findings do show newspaper reading and television viewing was significantly associated with candidate issue knowledge in the 2000 and 2004 presidential elections, but Internet use was only significantly associated with candidate issue knowledge in 2004 , and not in 2000 . The results demonstrate that newspaper reading, television viewing and Internet use were significantly associated with levels of candidate background knowledge in 2000 and 2004. Finally, newspaper reading and television viewing and Internet use were also significantly associated with likelihood to vote in both presidential elections.

I also expected results to show that Internet involvement was the primary source of media use associated with interpersonal discussion about political candidates in the presidential elections of 2000 and 2004 . This expectation was based on the interaction possibilities when using the Internet. Not only is the Internet a means of gathering information posted by candidates and commentators, but also allows citizens to e-mail, blog or otherwise interact with others. It seems this should encourage interpersonal 
discussion outside of the Internet as well. In 2000, interpersonal discussion was instead most significantly associated with television news viewing and newspaper reading, though Internet use was also significantly related to interpersonal discussion. In 2004, Internet use was the media form most strongly correlated with interpersonal discussion, followed by television viewing and newspaper reading. These results may be pointing to the increasing role of the Internet in political campaigns, specifically presidential campaigns, as a means of sparking citizens to interact with others about politics.

Weaver and Drew (2001) conducted a statewide survey in the state of Indiana and found Internet use for campaigning in the 2000 presidential election had less impact on voters' knowledge about candidates than expected. This study confirms that finding with a different set of data from the 2000 election, but finds that the impact did increase in the 2004 presidential election. This finding would indicate that the impact of Internet use could be increasing. There are still many, many questions to be answered about the role of the Internet in presidential campaigns, especially as its use grows in each successive presidential election year. The 2008 presidential elections will no doubt reflect a much more substantial role of the Internet in citizen knowledge levels and the use of the Internet for interaction among citizens and voters. Research concerning Internet use needs to continue in several different forms, answering many different types of questions.

Last, I expected to find that interpersonal discussion added significantly to the results of media use to increase candidate issue knowledge, candidate background knowledge and likelihood to vote. Interpersonal discussion did significantly predict levels of candidate issue knowledge and likelihood to vote in both the 2000 and 2004 
elections. However, interpersonal discussion did not significantly predict candidate background knowledge in the 2004 election, though it did in the 2000 election. This may be due to the lack of items on the 2004 survey to clearly measure candidate background knowledge. Only one item was used to measure this variable in the 2004 survey and therefore it may be less reliable than the 2000 finding (see Appendix A codebooks). More research would be required looking at the same variables over time to fully understand the role of interpersonal discussion in knowing about presidential candidates' backgrounds. However, it also seems likely that people may tend to engage in discussions focused on issues more than on candidates' backgrounds. In the 2004 election, Kerry's background as a Vietnam veteran became a large topic, especially when his military voting record was questioned in Bush campaign ads (see Chapter One for full discussion). It could also be that citizens focused so heavily on this aspect of Kerry's background that more obscure facts, like his experience as a prosecutor, were not wellknown even by those who were engaged in discussion.

\section{Importance of This Research}

This study is important to presidential elections for two basic reasons. First, the results are of benefit to the candidates themselves. In practical terms, the results will provide information to candidates about the type of media advertising and promotion that may influence voters most. If candidates want to focus on educating the populace about their background, which media sources would be of primary use to them? Many candidates have only been using the Internet for a few years; how does their Internet campaign affect voters? Secondly, these results provide evidence that interpersonal discussion of political issues is critical to voters' decision processes. As long suspected 
by communication scholars, the media themselves may have effect on knowledge levels and actions taken by voters, but so does the interpersonal communication and discussion between citizens. This discussion obviously adds to the level of knowledge about candidates' stand on issues, their background and increases the likelihood of voting. But how can candidates encourage interaction among citizens, discussion at home and at work? If interpersonal discussion among people at work or home can be sparked by online blogs and interactive websites, perhaps this is yet another reason for candidates to increase their online campaign efforts.

Presidential candidates are not the only beneficiaries of this research, however. Better understanding of public voting habits, how information is viewed, collected and shared with others, and how that information is used to gain knowledge and make decisions has far-reaching implications to political campaigns and other political endeavors. Policy changes are also often promoted and discussed via these same media forms. These findings could influence the use of media in other national, state and local campaigns and policy promotions.

\section{Weaknesses of this Study}

One weakness of this study is the lack of comparable data over several presidential election cycles. It is difficult, if not impossible, to illuminate any patterns in the findings based on survey results from only two elections. Also, because the NAES survey was first conducted in the 2000 election cycle, adjustments were made in the 2004 election cycle survey. Language for some items was adjusted, what had been one item on the 2000 survey was sometimes broken into more detail in the second survey, and some items were dropped. These changes make comparison across the surveys more 
challenging.

Another weakness pointed out several times in the text of this study is that candidate background knowledge was difficult to measure using the 2004 data. A singleitem measure was used and was certainly not ideal for measuring what respondents knew about the two presidential candidates. But a single-item measure was also used for newspaper reading, interpersonal discussion and Internet use in the 2000 data, and for newspaper reading and television viewing in the 2004 data. Feldman and Price (2008) report the same difficulty when using the NAES 2000 dataset for their study of the primary election.

In addition, some of the scales created to measure variables, had weak reliability (see Codebooks in Appendix A for reports of reliability on all created scales). For the scales created with the 2000 data (television viewing, candidate background knowledge, political involvement) the reliability hovered around $\alpha=.60$ (only candidate issue knowledge was higher at $\alpha=.73$ ). The 2004 scale created for Internet use, which included accessing information online and discussing politics online, has a low reliability $(\alpha=.53)$. The scale for interpersonal discussion had a reliability of $\alpha=.60$. In 2004 the scale for candidate issue knowledge $(\alpha=.73)$ and political involvement $(\alpha=.69)$ were relatively higher. Although lower reliabilities do not preclude the use of these scales, it might indicate that deeper thought about items used in the scale should be considered.

As with any mass survey conducted to collect a great deal of data as opposed to a survey designed specifically for the research project at hand, there are questions not asked that would be valuable to this research. In the datasets there are also missing data and limited data available on some items. A survey designed specifically for the 
questions and hypotheses of this study would provide much more detailed findings.

Newspaper reading, national television news viewing, Internet use and interpersonal communication regarding politics were treated as parallel forms of communication in this study. Though interrelated, each of these forms of communication involve different communication behaviors and each may have very different motivators (Cho, 2008). For instance, in the case of Internet use, it is required that the individual actually seek out the information or seek to be involved in online interaction about politics. It is possible, however, for individuals to inadvertently see political information on television or when reading the newspaper for a different purpose. Interpersonal discussion may be prompted by someone else at work, in the home or in another setting. Viewing television, reading a newspaper, using the Internet, or even listening to a conversation could be a passive communication behavior, but using the Internet or engaging in a conversation could also be an active communication behavior. Therefore to treat each of these communication activities as equal, without considering the level of motivation or engagement, is a short-coming.

Questions for Future Research

It seems that any research study simply begins to scratch the surface of an issue or question. Likewise, this study raises more questions that go well beyond its scope. First, the research needs to be continued over several presidential election campaign years. The Annenberg School at the University of Pennsylvania began data collection with this survey instrument, the NAES of the EDP, in 2000 and changed the procedure and survey itself slightly in the second year of collection, 2004. The 2008 presidential election data has been collected, but has not yet been made available for researchers. Once available, 
the 2008 election data may show significant differences with the previous two presidential election cycles because of the greatly increased role of the Internet, the unique circumstances of the candidates running (personalities of candidates definitely play a role in each presidential election) and the unique position of the country at the time of the election (circumstances of war, economics and other factors also influence campaigns). Even though each election cycle is unique, there may be patterns in media use and interpersonal discussion to be seen if the research was conducted over a period of several years and items on the survey were standardized so that results could be compared over the years. There are still questions to be answered about the impact of each unique election and the overall patterns of presidential elections. For instance, did having a sitting president running for reelection in 2004 make candidate background knowledge more common knowledge and thus less of an issue than in the 2000 election? Did understanding of policy and knowledge of candidates' stands on issues change depending on the overall political climate of the election?

There are also more specific questions to be answered about how citizens use the various forms of media. Do they specifically seek out political information when reading the newspaper or watching television news, or do they happen to access the information because they are doing these things? The NAES surveys ask simply how often respondents engage in the behavior of reading the paper or watching television news. The act of using the Internet for political information is more deliberate because the person must actually search for or actively access political information using this medium. What else do persons do to interact politically online? The 2004 survey asked more specific questions about this than did the 2000 survey (see Appendix A with 
codebooks for specific items), but more detail is still needed. Once people have garnered information from a media source or discussed information with another individual, how does that influence their voting decision?

Based on the low overall fit of the model including media use, interpersonal discussion and demographics, and their relationship with candidate issue and background knowledge and likelihood to vote there are obviously many other variables at work when it comes to citizens' political knowledge and voting behavior. Discovering what those variables are will continue to be an ongoing role for political and communication scholars.

This study provides one more context for looking at the role of interpersonal communication, along with the role of the media, when it comes to how people attain and use political information to make voting decisions. Though it does not definitively answer questions about how these means of sharing information interact or lead to voter knowledge and likelihood to vote, it does provide a needed basis for future research. 


\section{Table 1}

Descriptive Statistics for Variables in 2000 Presidential Election

\begin{tabular}{|c|c|c|c|}
\hline Variable & Mean & Std. Dev. & $\mathrm{N}$ \\
\hline Newspaper Reading $(0-3)$ & 1.51 & 1.06 & 6488 \\
\hline TV News Viewing $(0-3)$ & 1.71 & .89 & 6456 \\
\hline Internet Use $(0-4)$ & 1.01 & .83 & 4202 \\
\hline Interpersonal Discussion $(0-4)$ & 1.35 & .61 & 6484 \\
\hline Candidate Issue Knowledge (0-1) & .19 & .25 & 6508 \\
\hline Candidate Background Knowledge (0-1) & .29 & .26 & 6508 \\
\hline Political Involvement (1-2) & 1.09 & .19 & 4163 \\
\hline Educational Level (1-9) & 5.89 & 2.17 & 4163 \\
\hline \multicolumn{4}{|c|}{$\begin{array}{l}\text { Note: Range of the variable is reported in parentheses following the variable name. } \\
\text { Frequencies for other demographic variables not included here are found in Table } 13 \text { in } \\
\text { Appendix B. }\end{array}$} \\
\hline
\end{tabular}




\section{Table 2}

Descriptive Statistics for Variables in 2004 Presidential Election

\begin{tabular}{|c|c|c|c|}
\hline Variable & Mean & Std. Dev. & $\mathrm{N}$ \\
\hline Newspaper Reading (0-4) & 2.27 & 1.44 & 8664 \\
\hline TV News Viewing (0-4) & 2.58 & 1.36 & 8664 \\
\hline Internet Use (0-7) & .84 & 1.53 & 8664 \\
\hline Interpersonal Discussion (0-7) & 1.82 & 1.84 & 8664 \\
\hline Candidate Issue Knowledge (0-1) & .21 & .22 & 8664 \\
\hline Candidate Background Knowledge (0-1) & .34 & .47 & 8664 \\
\hline Political Involvement (1-2) & .05 & .16 & 8664 \\
\hline Educational Level (1-9) & 5.74 & 2.29 & 8609 \\
\hline \multicolumn{4}{|c|}{$\begin{array}{l}\text { Note: Range of the variable is reported in parentheses following the variable name. } \\
\text { Frequencies for other demographic variables not included here are found in Table } 14 \text { in } \\
\text { Appendix B. }\end{array}$} \\
\hline
\end{tabular}




\section{Table 3}

Correlation Matrix for Variables in 2000 Presidential Election

\begin{tabular}{|c|c|c|c|c|c|c|c|}
\hline & 1 & 2 & 3 & 4 & 5 & 6 & 7 \\
\hline $\begin{array}{l}\text { Newspaper } \\
\text { Reading }\end{array}$ & - & $\begin{array}{l}.255 \\
.000\end{array}$ & $\begin{array}{l}.092 \\
.000\end{array}$ & $\begin{array}{l}.196 \\
.000\end{array}$ & $\begin{array}{l}.100 \\
.000\end{array}$ & $\begin{array}{l}.167 \\
.000\end{array}$ & $\begin{array}{l}.215 \\
.000\end{array}$ \\
\hline $\begin{array}{l}\text { TV News } \\
\text { Viewing }\end{array}$ & & - & $\begin{array}{l}.139 \\
.000\end{array}$ & $\begin{array}{l}.246 \\
.000\end{array}$ & $\begin{array}{l}.083 \\
.000\end{array}$ & $\begin{array}{l}.102 \\
.000\end{array}$ & $\begin{array}{l}.186 \\
.000\end{array}$ \\
\hline $\begin{array}{l}\text { Internet } \\
\text { Use }\end{array}$ & & & - & $\begin{array}{l}.105 \\
.000\end{array}$ & $\begin{array}{l}.023 \\
.128\end{array}$ & $\begin{array}{l}.057 \\
.000\end{array}$ & $\begin{array}{l}.065 \\
.000\end{array}$ \\
\hline $\begin{array}{l}\text { Interpersonal } \\
\text { Discussion }\end{array}$ & & & & - & $\begin{array}{l}.084 \\
.000\end{array}$ & $\begin{array}{l}.122 \\
.000\end{array}$ & $\begin{array}{l}.165 \\
.000\end{array}$ \\
\hline $\begin{array}{l}\text { Candidate } \\
\text { Issue } \\
\text { Knowledge }\end{array}$ & & & & & - & $\begin{array}{l}.459 \\
.000\end{array}$ & $\begin{array}{l}.098 \\
.000\end{array}$ \\
\hline $\begin{array}{l}\text { Candidate } \\
\text { Background } \\
\text { Knowledge } \\
\text { Voted }\end{array}$ & & & & & & - & $\begin{array}{l}.151 \\
.000\end{array}$ \\
\hline $\begin{array}{l}\text { Note: The to } \\
\text { number repo } \\
\text { exception of }\end{array}$ & mbe & $\begin{array}{l}\text { he str } \\
\text { he } p \\
\text { n betv }\end{array}$ & $\begin{array}{l}\text { th of c } \\
\text { te. All } \\
\text { Inter }\end{array}$ & $\begin{array}{l}\text { ation } \\
\text { relatic } \\
\text { Jse ar }\end{array}$ & $\begin{array}{l}\text { veen } t \\
\text { re at } \\
\text { andid }\end{array}$ & $\begin{array}{l}\text { riable } \\
1 \text { wit } \\
\text { sue K }\end{array}$ & $\begin{array}{l}\text { The } \\
\text { ledge. }\end{array}$ \\
\hline
\end{tabular}




\section{Table 4}

Correlation Matrix for Variables in 2004 Presidential Election

\begin{tabular}{|c|c|c|c|c|c|c|c|}
\hline & 1 & 2 & 3 & 4 & 5 & 6 & 7 \\
\hline $\begin{array}{l}\text { Newspaper } \\
\text { Reading }\end{array}$ & - & $\begin{array}{l}.262 \\
.000\end{array}$ & $\begin{array}{l}.134 \\
.000\end{array}$ & $\begin{array}{l}.176 \\
.000\end{array}$ & $\begin{array}{l}.077 \\
.000\end{array}$ & $\begin{array}{l}.033 \\
.002\end{array}$ & $\begin{array}{l}.191 \\
.000\end{array}$ \\
\hline $\begin{array}{l}\text { TV News } \\
\text { Viewing }\end{array}$ & & - & $\begin{array}{l}.150 \\
.000\end{array}$ & $\begin{array}{l}.183 \\
.000\end{array}$ & $\begin{array}{l}.086 \\
.000\end{array}$ & $\begin{array}{l}.076 \\
.000\end{array}$ & $\begin{array}{l}.181 \\
.000\end{array}$ \\
\hline $\begin{array}{l}\text { Internet } \\
\text { Use }\end{array}$ & & & - & $\begin{array}{l}.307 \\
.000\end{array}$ & $\begin{array}{l}.091 \\
.000\end{array}$ & $\begin{array}{l}.082 \\
.000\end{array}$ & $\begin{array}{l}.093 \\
.000\end{array}$ \\
\hline $\begin{array}{l}\text { Interpersonal } \\
\text { Discussion }\end{array}$ & & & & - & $\begin{array}{l}.102 \\
.000\end{array}$ & $\begin{array}{l}.067 \\
.000\end{array}$ & $\begin{array}{l}.107 \\
.000\end{array}$ \\
\hline $\begin{array}{l}\text { Candidate } \\
\text { Issue } \\
\text { Knowledge }\end{array}$ & & & & & - & $\begin{array}{l}.476 \\
.000\end{array}$ & $\begin{array}{l}.123 \\
.000\end{array}$ \\
\hline $\begin{array}{l}\text { Candidate } \\
\text { Background } \\
\text { Knowledge }\end{array}$ & & & & & & - & $\begin{array}{l}.077 \\
.000\end{array}$ \\
\hline Voted & & & & & & & $\underline{-}$ \\
\hline
\end{tabular}




\section{Table 5}

Linear Regression on Candidate Issue Knowledge in 2000 Presidential Election

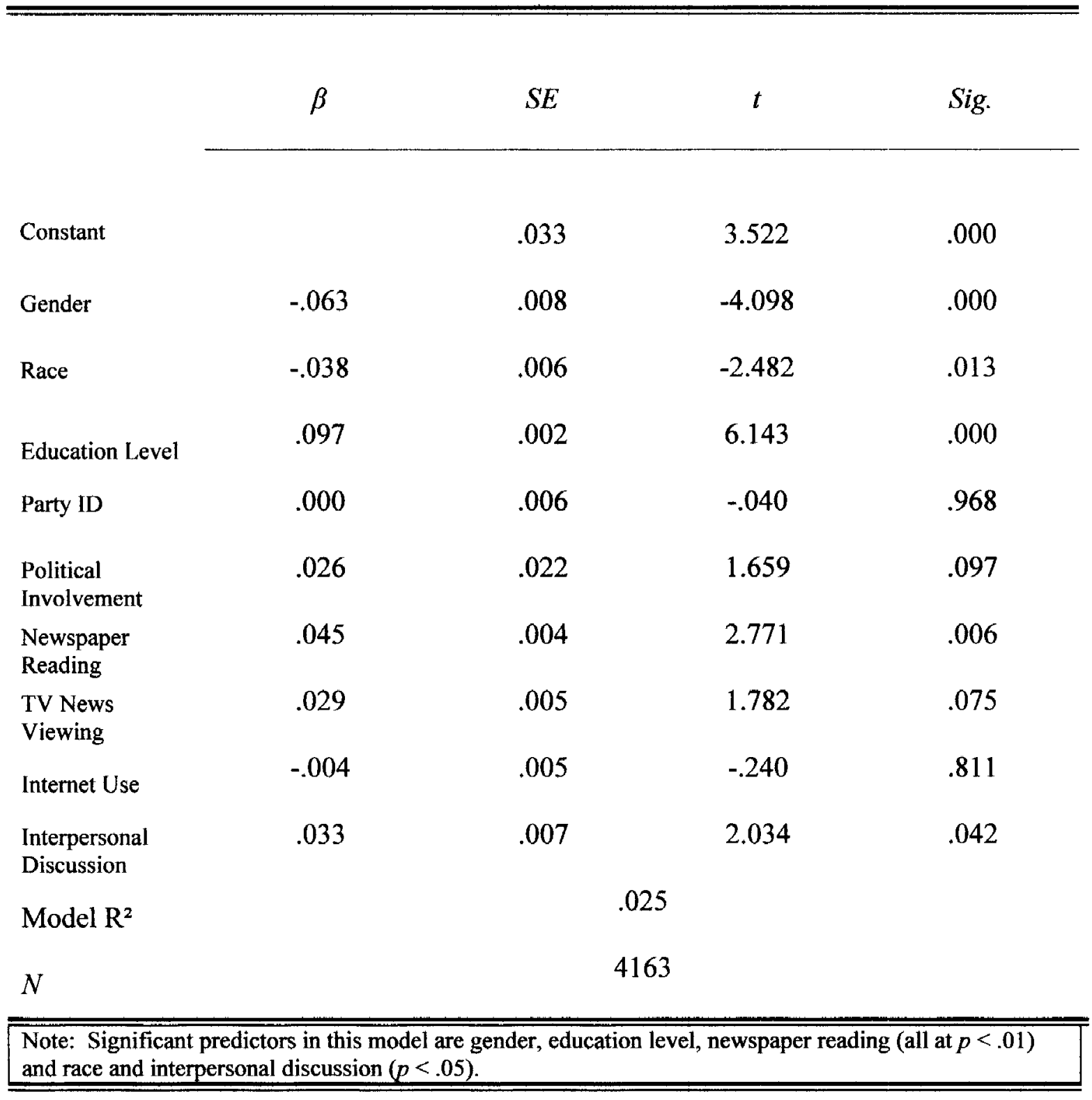




\section{Table 6}

Linear Regression on Candidate Issue Knowledge in 2004 Presidential Election

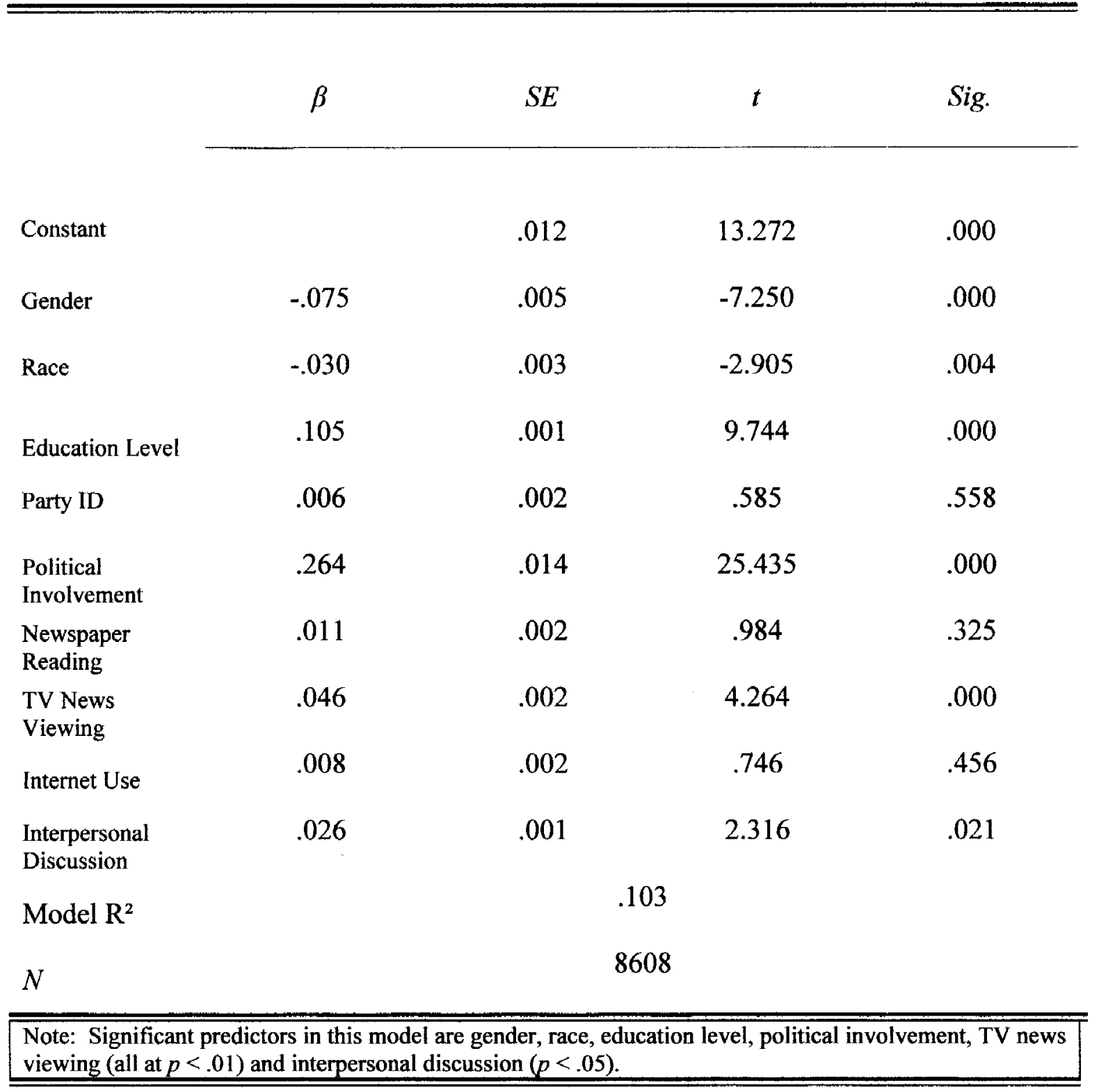




\section{Table 7}

Linear Regression on Candidate Background Knowledge in 2000 Presidential Election

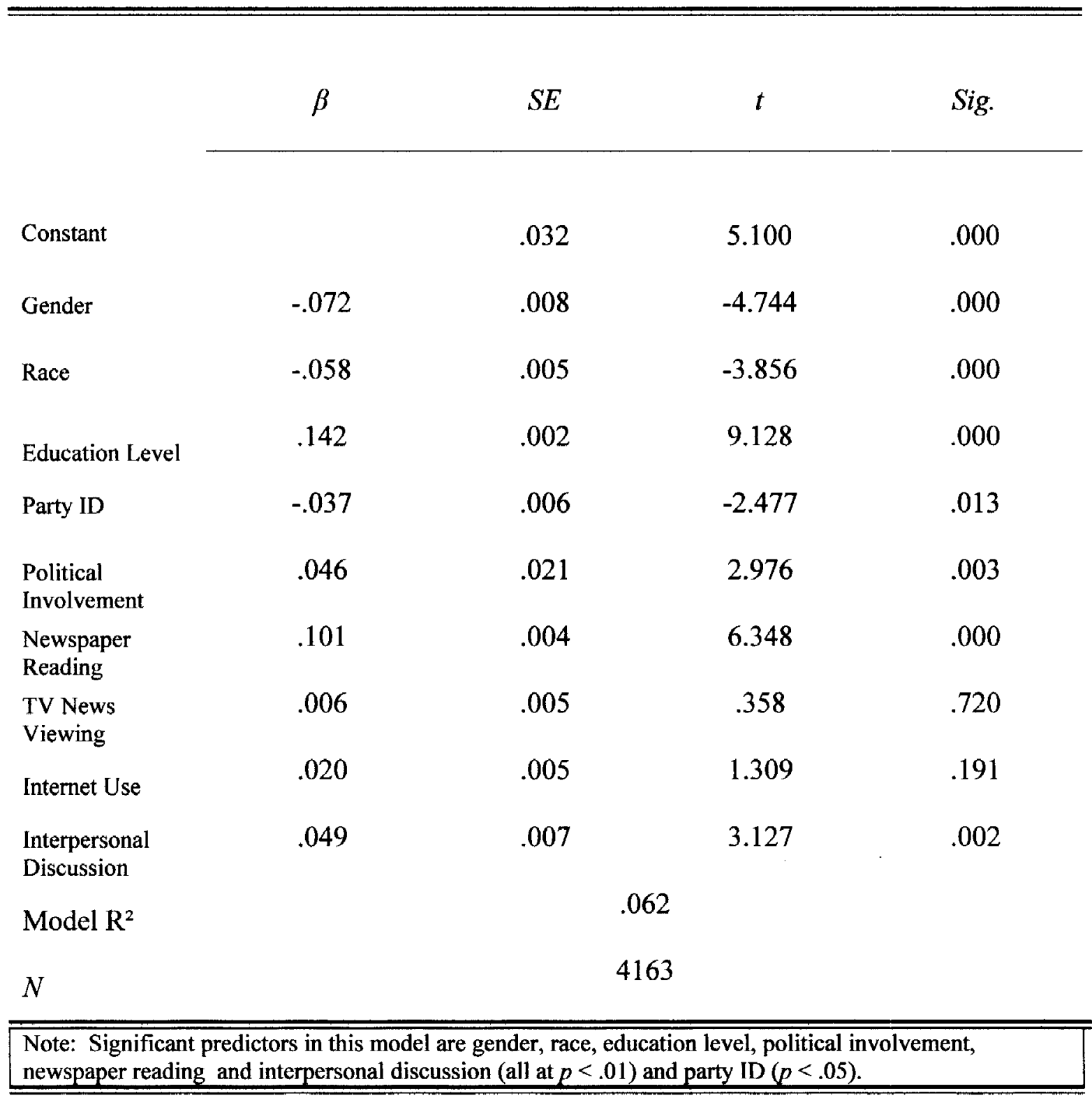




\section{Table 8}

Linear Regression on Candidate Background Knowledge in 2004 Presidential Election

\begin{tabular}{|c|c|c|c|c|}
\hline & $\beta$ & $S E$ & $t$ & Sig. \\
\hline Constant & & .027 & 6.862 & .000 \\
\hline Gender & -.026 & .010 & -2.489 & .013 \\
\hline Race & -.010 & .006 & -.918 & .359 \\
\hline Education Level & .090 & .002 & 8.121 & .000 \\
\hline Party ID & .021 & .005 & 1.947 & .052 \\
\hline $\begin{array}{l}\text { Political } \\
\text { Involvement }\end{array}$ & .167 & .031 & 15.604 & .000 \\
\hline $\begin{array}{l}\text { Newspaper } \\
\text { Reading }\end{array}$ & -.021 & .004 & -1.859 & .063 \\
\hline $\begin{array}{l}\text { TV News } \\
\text { Viewing }\end{array}$ & .057 & .004 & 5.152 & .000 \\
\hline Internet Use & .029 & .004 & 2.564 & .010 \\
\hline $\begin{array}{l}\text { Interpersonal } \\
\text { Discussion }\end{array}$ & .008 & .003 & .662 & .508 \\
\hline Model $\mathrm{R}^{2}$ & \multicolumn{4}{|c|}{.048} \\
\hline$N$ & \multicolumn{4}{|c|}{8608} \\
\hline $\begin{array}{l}\text { Note: Significant } \\
\text { at } p<.01 \text { ) and ge } \\
\text { candidate backgro } \\
\text { conclusions about }\end{array}$ & $\begin{array}{l}\text { rs in this } \\
\text { Internet } \\
\text { wledge } \mathrm{w} \\
\text { able mus }\end{array}$ & $\begin{array}{l}\text { ation } 1 \\
\text { d party } \\
\text { ith onl }\end{array}$ & $\begin{array}{l}\text { involvem } \\
\text { The dep } \\
\text { m the } 200\end{array}$ & $\begin{array}{l}\text { viewir } \\
\text { ble of } \\
\text { vey so }\end{array}$ \\
\hline
\end{tabular}




\section{Table 9}

Binary Logistic Regression on Likelihood to Vote in 2000 Presidential Election

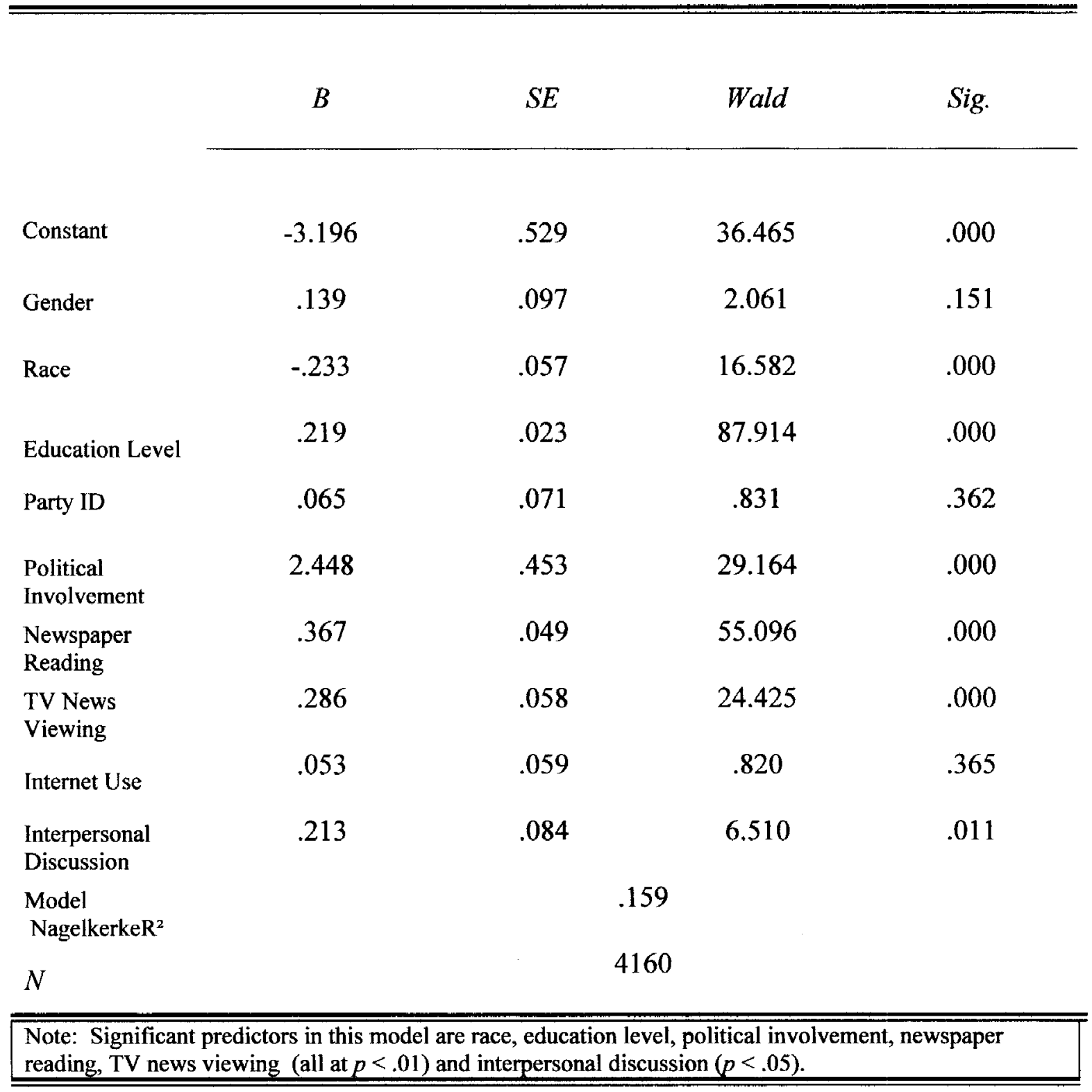




\section{Table 10}

Binary Logistic Regression on Likelihood to Vote in the 2004 Presidential Election

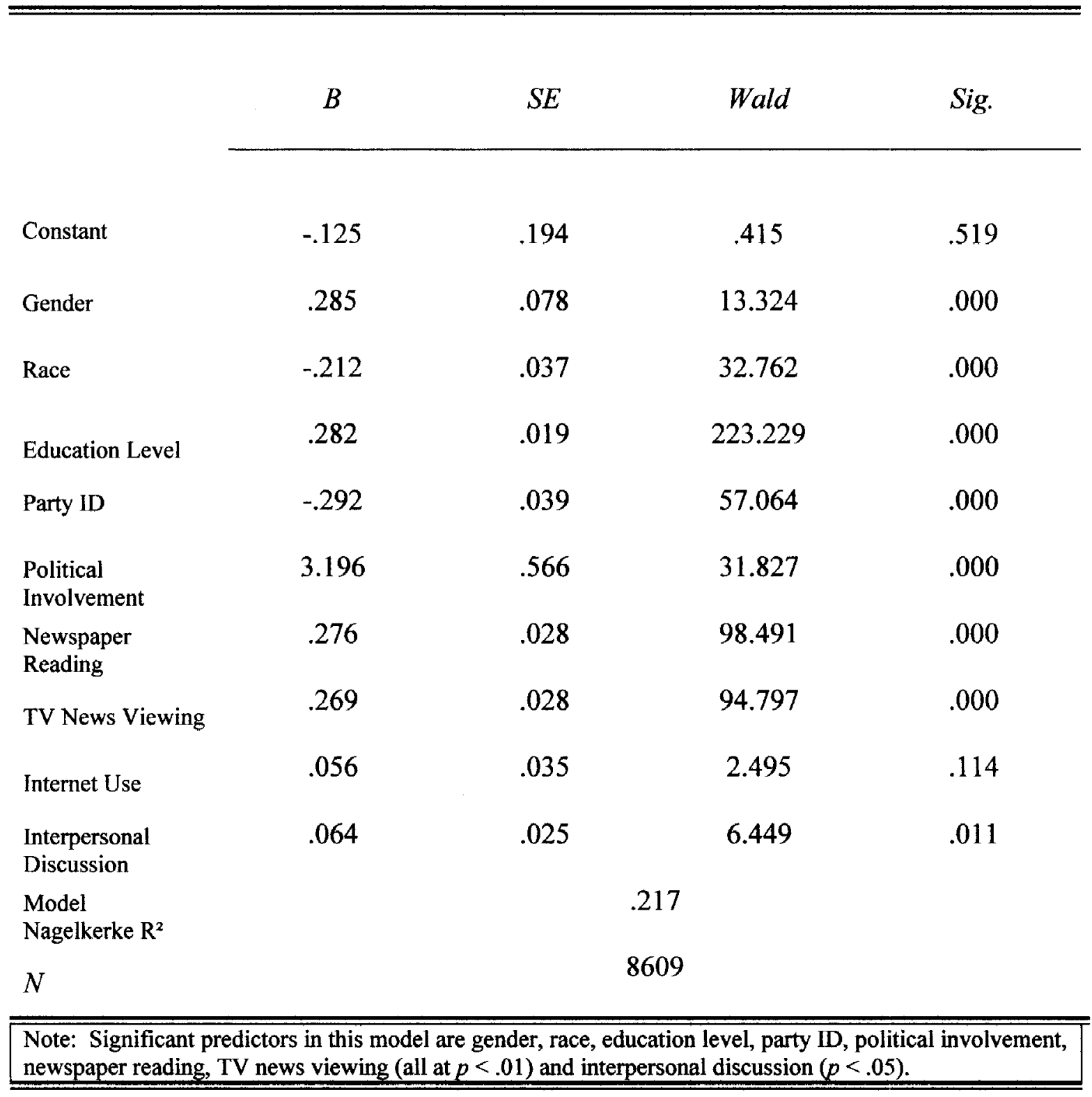




\section{Table 11}

Crosstabs of Likelihood to Vote and Interpersonal Discussion in 2000 Presidential Election

\begin{tabular}{|c|c|c|c|c|}
\hline Voted & \multicolumn{3}{|c|}{ Interpersonal Discussion } & Total \\
\hline & Never & $\begin{array}{l}\text { Less than } \\
\text { few times } \\
\text { a month }\end{array}$ & $\begin{array}{c}\text { Few } \\
\text { times a } \\
\text { month }\end{array}$ & \\
\hline No & $\begin{array}{l}42 \% \\
(201)\end{array}$ & $\begin{array}{l}16 \% \\
(532)\end{array}$ & $\begin{array}{l}12 \% \\
(329)\end{array}$ & $\begin{array}{c}16 \% \\
(1062)\end{array}$ \\
\hline Yes & $\begin{array}{l}58 \% \\
(280)\end{array}$ & $\begin{array}{c}84 \% \\
(2726)\end{array}$ & $\begin{array}{c}88 \% \\
(2407)\end{array}$ & $\begin{array}{c}84 \% \\
(5413)\end{array}$ \\
\hline Total & $\begin{array}{l}100 \% \\
(481) \\
\end{array}$ & $\begin{array}{r}100 \% \\
(3258) \\
\end{array}$ & $\begin{array}{r}100 \% \\
(2736) \\
\end{array}$ & $\begin{array}{r}100 \% \\
(6475) \\
\end{array}$ \\
\hline
\end{tabular}




\section{Table 12}

Crosstabs of Likelihood to Vote and Interpersonal Discussion in 2004 Presidential Election

\begin{tabular}{|c|c|c|c|c|c|c|}
\hline \multirow[t]{2}{*}{ Voted } & \multicolumn{5}{|c|}{ Interpersonal Discussion } & \multirow[t]{2}{*}{ Total } \\
\hline & Never & $\begin{array}{c}\text { Two } \\
\text { days or } \\
\text { less a } \\
\text { week }\end{array}$ & $\begin{array}{c}\text { Three to } \\
\text { four days } \\
\text { a week }\end{array}$ & $\begin{array}{c}\text { Four to } \\
\text { five } \\
\text { days a } \\
\text { week }\end{array}$ & $\begin{array}{c}\text { More } \\
\text { than five } \\
\text { days a } \\
\text { week }\end{array}$ & \\
\hline No & $\begin{array}{l}16 \% \\
(379)\end{array}$ & $\begin{array}{c}9 \% \\
(309)\end{array}$ & $\begin{array}{c}6 \% \\
(133)\end{array}$ & $\begin{array}{l}5 \% \\
(21)\end{array}$ & $\begin{array}{l}7 \% \\
(25)\end{array}$ & $\begin{array}{l}10 \% \\
(867)\end{array}$ \\
\hline Yes & $\begin{array}{c}84 \% \\
(1952)\end{array}$ & $\begin{array}{c}91 \% \\
(3095)\end{array}$ & $\begin{array}{c}94 \% \\
(2016)\end{array}$ & $\begin{array}{c}95 \% \\
(397)\end{array}$ & $\begin{array}{c}93 \% \\
(337)\end{array}$ & $\begin{array}{c}90 \% \\
(7797)\end{array}$ \\
\hline Total & $\begin{array}{c}100 \% \\
(2331)\end{array}$ & $\begin{array}{c}100 \% \\
(3404)\end{array}$ & $\begin{array}{c}100 \% \\
(2149)\end{array}$ & $\begin{array}{l}100 \% \\
(418)\end{array}$ & $\begin{array}{l}100 \% \\
(362)\end{array}$ & $\begin{array}{r}100 \% \\
(8664)\end{array}$ \\
\hline
\end{tabular}




\section{REFERENCES}

Abrajano, M. \& Singh, S. (2009). Examining the link between issue attitudes and news source: The case of Latinos and immigration reform. Political Behavior, 31(1): 130.

Annenberg Public Policy Center. (2008). National Annenberg Election Surveys Data Sets. Retrieved on Nov. 24, 2008, from http://www.annenbergpublicpolicycenter.org

Brians, C. L. \& Wattenberg, M.P. (1996). Campaign issue knowledge and salience: Comparing reception from TV news, TV commercials and newspapers. American Journal of Political Science, 40(1): 172-193.

Cho, J. (2008). Political ads and citizen communication. Communication Research, 35(4): $423-451$.

Cohen, B. C. (1963). The press and foreign policy. Westport, CT: Greenwood Press.

Craig, S.C., Kane, J.G. \& Gainous, J. (2005). Issue-Related learning in a gubernatorial campaign: A panel study. Political Communication, 22(4): 483-503.

de Boer, C. \& Velthuijsen, A. S. (2001). Participation in conversations about the news. International Journal of Public Opinion Research, 13(2): 140 - 158.

Druckman, J. N. \& Parkin, M. (2005). The impact of media bias: How editorial slant affects voters. The Journal of Politics, 67(4): 1030-1049.

Entman, R. M. (1993). Framing: Toward classification of a fractured paradigm. Journal 
of Communication, 43(4): 51-58.

Eveland Jr., W. P., Hayes, A.F., Shah, D. V. \& Kwak, N. (2005). Understanding the relationship between communication and political knowledge: A model comparison approach using panel data. Political Communication, 22(4): 423-446.

Eveland Jr., W. P., Hayes, A.F., Shah, D. V. \& Kwak, N. (2005). Observations on estimation of communication effects on political knowledge and a test of intra communication mediation. Political Communication, 22(4): 505-509.

Falk, E. (2008). Women for President: Media bias in eight campaigns. Chicago, IL: University of Illinois Press.

Feldman, L. \& Price, V. (2008). Confusion or enlightenment?: How exposure to disagreement moderates the effects of political discussion and media use on candidate knowledge. Communication Research, 35(1): 61-87.

Fogarty, B. J. \& Wolak, J. (2009). The effects of media interpretation for citizen evaluations of politicians' messages. American Politics Research, 37(1): 129-154.

Frank, T. (2004). What's the Matter with Kansas?: How Conservatives Won the Heart of America. New York, NY: Henry Holt and Company

Gerbner, G. \& Gross, L. (1976). Living with television: The violence profile. Journal of Communication, 26(2): 173-199.

Goldenberg, E.N. \& Traugott, M. W. (1987). Mass media in U.S. elections. Legislative Studies Quarterly, 12(3): 317-339.

Gueorguieva, V. (2008). Voters, MySpace and YouTube: The impact of alternative communication channels on the 2006 election cycle and beyond. Social Science Computer Review, 26(3): 288-300. 
Holbert, R. L. (2005). Intramedia mediation: The cumulative and complementary effects of news media use. Political Communication, 22(4): 447-461.

Holbert, R. L., LaMarre, H. L. \& Landreville, K. D. (2009). Fanning the flames of a partisan divide: Debate viewing, vote choice, and perceptions of vote count accuracy. Communication Research, 36(2): 155-177.

Huckfeldt, R. \& Sprague, J. (1995). Citizens, politics, and social communication: Information and influence in an election campaign. New York, NY: Cambridge University Press.

Iyengar, S. (1991). Is anyone responsible? How television frames political issues. Chicago, IL: University of Chicago Press.

Iyengar, S. \& Kinder, D. R. (1987). News that matters. Chicago, IL: University of Chicago Press.

Johnston, R. (2006). Party identification: Unmoved mover or sum of preferences? Annual Review of Political Science, 9, 329-351.

Kahane, L. H. (2001). Regression basics. Thousand Oaks, CA: Sage Publications.

Kahneman, D. \& Tversky, A. (1984). Choices, values and frames. American Psychologist, 39(4): 341-350.

Katz, E. \& Lazarsfeld, P. F. (1955). Personal influence: The part played by people in the flow of mass communication. Glencoe, IL: Free Press of Glencoe.

Kurtz, H. (May 9, 2004). Candidate's ads switch the focus to Kerry. Washington Post, A4.

Kwak, N., Williams, A. E., Wang, X. \& Lee, H. (2005). Talking politics and engaging politics: An examination of the interactive relationships between structural features 
of political talk and discussion engagement. Communication Research, 32(l): 87111.

Lazarsfeld, P.F. \& Merton, R. K. (1948). Mass communication, popular taste and organized social action. In L. Bryson, ed. The communication of ideas, pp. 95-118. New York, NY: Institute for Religious and Social Studies.

Lee, N., McLeod, D. \& Shah, D. V. (2008). Framing policy debates: Issue dualism, journalistic frames, and opinions on controversial policy issues. Communication Research, 35(5): 695-718.

Lenart, S. (1994). Shaping political attitudes: The impact of interpersonal communication and mass media. Thousand Oaks, CA: Sage.

Lowery, S. A. \& DeFleur, M. L. (1995). Milestones in mass communication research: Media effects. White Plains, NY: Longman Publishers.

McCombs, M. E. \& Shaw, D. L. (1972). The agenda-setting function of mass media. Public Opinion Quarterly, 36(2): 176-187.

McLeod, J.M., Scheufele, D. A. \& Moy, P. (1999). Community, communication, and participation: The role of mass media and interpersonal discussion in local political participation. Political Communication, 16(3): 315-336.

Mutz, D. C. \& Martin, P.S. (2001). Facilitating communication across lines of political difference: The role of mass media. American Political Science Review, 95(1): 97114.

Rice, A. (2003). The use of blogs in the 2004 presidential election. Retrieved on May 27, 2009. http://www.campaignsonline.org/reports/blog.pdf

Scheufele, D. A. (2000). Talk or conversation?: Dimensions of interpersonal discussion 
and their implications for participatory democracy. Journalism and Mass Communication Quarterly, 77(4): 727-743.

Scheufele, D. A. (2002). Examining differential gains from mass media and their implications for participatory behavior. Communication Research, 29 (1), 46 - 65.

Weaver, D. \& Drew, D. (2001). Voter learning and interest in the 2000 Presidential election: Did the media matter? Journalism and Mass Communication Quarterly, 78(4): $787-797$.

Weimann, G. (1982). On the importance of marginality: One more step into the two-step flow of communication. American Sociological Review, 47(6): 764-773.

West, D.M. (2004). Advertising and citizen voting behavior. In D. Graber, D. McQuail and P. Norris, eds. The politics of news: the news of politics, pp. 141-160. Washington, D.C.: CQ Press.

Wyatt, R., Katz, E. \& Kim, J. (2000). Bridging the spheres: Political and personal conversation in public and private spaces. Journal of Communication, 50(1): 71 - 92. 


\section{APPENDIX A}

\section{NAES Codebook}

Newspaper Reading - one item

How much attention did the respondent pay to political news in the newspaper

Recoded to $-0=$ none

$1=$ not too much

$2=$ some

$3=$ great deal

TV news viewing - two items $(\alpha=.59)$

Respondent paid attention to political news on network TV

Recoded to $-0=$ none

$1=$ not too much

2 = some

$3=$ great deal

Respondent paid attention to political news on cable TV

Recoded to $-0=$ none

$1=$ not too much

$2=$ some

$3=$ great deal

Once recoded the items were combined and standardized, dividing by two to create an overall index of TV news viewing

Internet use - one item

Paid attention to online information about the presidential campaign

Recoded to $-0=$ never

$1=$ less often than few times a month

$2=$ few times a month

$3=$ few times a week

$4=$ every day 
Interpersonal Discussion - one item

Discussed politics with family or friends in presidential campaign

Recoded to $-0=$ never

$1=$ less often than few times a month

$2=$ few times a month

$3=$ few times a week

4 = every day

Voted - one item

Voted in the general election

Recoded to $-1=$ no

$2=$ yes

Candidate Issue Knowledge -12 items $(\alpha=.73)$

Bush or Gore favors biggest tax cut

Bush or Gore favors using Medicare surplus to cut taxes

Bush or Gore favors doubling per-child tax deduction

Bush or Gore favors investing Social Security in stock market

Bush or Gore favors school vouchers

Bush or Gore favors restricting abortion

Recoded to $-1=$ right (Bush)

All other items $=0=$ wrong

Bush or Gore favors paying down the debt most

Bush or Gore favors universal health care for children

Bush or Gore favors right to sue HMOs

Bush or Gore favors handgun licenses

Bush or Gore favors soft money ban

Recoded to $-1=$ right (Gore)

All other items $=0=$ wrong

Bush or Gore favors death penalty

Recoded to $-1=$ right (Both)

All other items $=0=$ wrong

Once recoded these responses were standardized by dividing by 12 , which indicates the average number of correct responses on the 12 items. 
Candidate Background Knowledge - five items $(\alpha=.61)$

Bush or Gore is governor

Bush or Gore served in Vietnam

Bush or Gore spoke at Bob Jones University

Bush or Gore owned a baseball team

Bush or Gore is son of a senator

Recoded to $-1=$ right

All other items recoded to 0

Standardized by adding the responses and dividing by five.

Political Involvement - four items $(\alpha=.59)$

Attended meeting for presidential candidate in fall campaign

Recoded to indicate directionality

$$
\begin{aligned}
& 2=\text { yes } \\
& 1=\text { no }
\end{aligned}
$$

Did other work for a presidential candidate in fall campaign

Recoded to indicate directionality

$$
\begin{aligned}
& 2=\text { yes } \\
& 1=\text { no }
\end{aligned}
$$

Gave money to presidential candidate in fall campaign

Recoded to indicate directionality

$$
\begin{aligned}
& 2=\text { yes } \\
& 1=\text { no }
\end{aligned}
$$

Displayed sign for presidential candidate in fall campaign

Recoded to indicate directionality

$$
\begin{aligned}
& 2=\text { yes } \\
& 1=\text { no }
\end{aligned}
$$

The Political Involvement Index was created by adding these four items and dividing by four for a standardized index. 


\section{Political ID}

$$
\begin{aligned}
& 1=\text { Republican } \\
& 2=\text { Democrat }
\end{aligned}
$$

Gender

$$
\begin{aligned}
& 1=\text { Male } \\
& 2=\text { Female }
\end{aligned}
$$

$\underline{\text { Race }}$

$$
\begin{aligned}
& 1=\text { White } \\
& 2=\text { Black } \\
& 3=\text { Asian } \\
& 4=\text { Other }
\end{aligned}
$$

(In 2004, American Indian was added as an option, but not included in 2000 NAES.)

$$
\begin{aligned}
& \text { Educational Level } \\
& 1=\text { Grade } 8 \text { or lower } \\
& 2 \text { = some high school } \\
& 3=\text { high school diploma or equivalent } \\
& 4=\text { technical or vocation school after high school } \\
& 5=\text { some college, no degree } \\
& 6=\text { associate or 2-year degree } \\
& 7=4 \text {-year degree } \\
& 8=\text { grad or professional school, no degree } \\
& 9=\text { graduate or professional degree }
\end{aligned}
$$




\section{NAES Codebook}

Newspaper Reading - one item

How much attention did the respondent pay to political news in the newspaper in the past week

Recoded to $-0=$ none

$1=$ not too much

$2=$ some

$3=$ quite a bit

$4=$ great deal

TV News Viewing - one item

Respondent paid attention to political news on network or cable TV in the past week

Recoded to $-0=$ none

$1=$ not too much

$2=$ some

$3=$ quite a bit

$4=$ great deal

Internet Use - two items $(\alpha=.53)$

Accessed political information online in the past week

0-7 for number of days accessed

Discussed politics online in the past week

0-7 for number of days discussed

These two items were added and divided by two to standardize the scale.

Interpersonal Discussion - two items $(\alpha=.60)$

Discussed politics with family or friends in past week

$0-7$ for number of days discussed

Discussed politics with others at work in the past week

$0-7$ for number of days discussed

These two items were added and divided by two to standardize the scale. 
Candidate Issue Knowledge - eight items $(\alpha=.73)$

Recoded to $1=$ right and $0=$ wrong

Know if Bush or Kerry favors making Bush tax cuts permanent

Know if Bush or Kerry favors making union organizing easier

Know if Bush or Kerry favors government health insurance for children and workers

Know if bush or Kerry favors Medicare Prescription Law

Know if Bush or Kerry favors Social Security in the stock market

Know if Bush or Kerry favors Patriot Act

Know if Bush or Kerry favors stem cell funding

Know if Bush or Kerry favors assault weapons ban

Standardized by dividing the total result by eight.

Candidate Background Knowledge - one item

Know if Bush or Kerry is a former prosecutor

Recoded to $1=$ right or $0=$ wrong

Political Involvement - four items $(\alpha=.69)$

Attended meeting for presidential candidate in fall campaign

Recoded to indicate directionality

$$
\begin{aligned}
& 2=\text { yes } \\
& 1=\text { no }
\end{aligned}
$$

Did other work for a presidential candidate in fall campaign

Recoded to indicate directionality

$$
\begin{aligned}
& 2=\text { yes } \\
& 1=\text { no }
\end{aligned}
$$

Gave money to presidential candidate in fall campaign

Recoded to indicate directionality

$$
\begin{aligned}
& 2=\text { yes } \\
& 1=\text { no }
\end{aligned}
$$

Displayed sign for presidential candidate in fall campaign

Recoded to indicate directionality

$$
\begin{aligned}
& 2=\text { yes } \\
& 1=\text { no }
\end{aligned}
$$

The Political Involvement Index was created by adding these four variables and dividing by four for a standardized index. 


\section{Political ID}

$1=$ Republican

$2=$ Democrat

$3=$ Independent

Gender

$$
1=\text { Male }
$$

$2=$ Female

Race

$$
\begin{aligned}
& 1=\text { White } \\
& 2=\text { Black } \\
& 3=\text { Asian } \\
& 4=\text { American Indian } \\
& 5=\text { Other }
\end{aligned}
$$

Educational Level

$$
\begin{aligned}
& 1=\text { Grade } 8 \text { or lower } \\
& 2=\text { some high school } \\
& 3=\text { high school diploma or equivalent } \\
& 4=\text { technical or vocation school after high school } \\
& 5=\text { some college, no degree } \\
& 6=\text { associate or } 2 \text {-year degree } \\
& 7=4 \text {-year degree } \\
& 8=\text { grad or professional school, no degree } \\
& 9=\text { graduate or professional degree }
\end{aligned}
$$




\section{APPENDIX B}

\section{Table 13}

Frequencies for Variables in 2000 Presidential Election

\begin{tabular}{cc}
\multicolumn{2}{c}{ Voted } \\
Yes & No \\
\hline $84 \%$ & $16 \%$ \\
$(5413)$ & $(1062)$
\end{tabular}

\section{Gender}

Male

Female

$\begin{array}{lc}44 \% & 56 \% \\ (2861) & (3647)\end{array}$

\begin{tabular}{cccc} 
& \multicolumn{2}{c}{ Race } \\
White & Black & Asian & Other \\
\hline $87 \%$ & $7 \%$ & $1 \%$ & $5 \%$ \\
$(5653)$ & $(453)$ & $(59)$ & $(343)$
\end{tabular}

Party ID

Republican Democrat

$\begin{array}{lc}59 \% & 41 \% \\ (3439) & (2397)\end{array}$




\section{Table 14}

Frequencies for Variables in 2004 Presidential Election

\begin{tabular}{cc}
\multicolumn{2}{c}{ Voted } \\
Yes & No \\
\hline $90 \%$ & $10 \%$ \\
$(7797)$ & $(867)$
\end{tabular}

\section{Gender}

\begin{tabular}{cc} 
Male & Female \\
\hline $45 \%$ & $55 \%$ \\
$(3883)$ & $(4781)$
\end{tabular}

Race

\begin{tabular}{cccc} 
White & Black & Asian & Other \\
\hline $89 \%$ & $6 \%$ & $1 \%$ & \\
$(7598)$ & $(484)$ & $(99)$ & $4 \%$
\end{tabular}

Party ID

Republican $37 \%$
$(2928)$
Democrat

$36 \%$

(2909)
Independent

$27 \%$

(2174) 


\section{CURRICULUM VITAE}

NAME: $\quad$ Donna M. Elkins

ADDRESS: $\quad$ Department of Communication

1000 Community College Drive

Jefferson Community and Technical College

Louisville, KY 40214

DOB: $\quad$ Maysville, Kentucky - May 18, 1968

EDUCATION: B.A., Journalism/Government

Morehead State University

1986-1989

M. A., Mass Communication

Morehead State University

1990-1994

Ph.D., Interpersonal Communication

University of Kentucky

1998-2005

AWARDS: $\quad$ Kentucky Virtual University Online Teaching Excellence Award 2005

PROFESSIONAL SOCIETIES:

Kentucky Political Science Association

Kentucky Communication Association

Southern States Communication Association

National Communication Association

PUBLICATIONS:

Elkins, D. (2008). Book review: Lewis, Anthony. Freedom for the Thought That We Hate: A Biography of the First Amendment. New York, NY: Basic Books, 2007. In Free Speech Yearbook 2008. 
Dietrich, J., Elkins, D., Goldsmith, J. \& Welsh, J. (2006). KYVU Online Excellence Award Winners. Kentucky Journal for

Excellence in Teaching and Learning. Retrieved March 19, 2007, from http:// www.kentuckyjournalofexcellence.org

Violette, J., Payne, H., Elkins, D., \& Tillson, L. (2006). Closing the loop on assessment: Developing strategies for continuous improvement . In G. LaFleur (Ed.), The Nexus of Thought and Practice in the Communication Arts. Morehead, KY: KCA Press.

Elkins, D. M. (2003). Book review: Handbook of communication and social interaction skills. In Southern Communication Journal, 68,346 .

\section{NATIONAL MEETING PRESENTATIONS:}

Close Talkers, High Talkers, Low Talkers, Thank You Waves, and Tells: Analyzing Nonverbal Communication Norms As Seen in 'Seinfeld,' Southern American Popular Culture Association October 2008

Graduate Student Give and Take: An Exploration of the Mutual Influence That Graduate Teaching Assistants May Exert in Their Academic Departments, American Communication Association September 2000

Symbolizing Life: Creation and Use of Symbols in Small Group Interactions, International Narrative Conference - November 1999 